
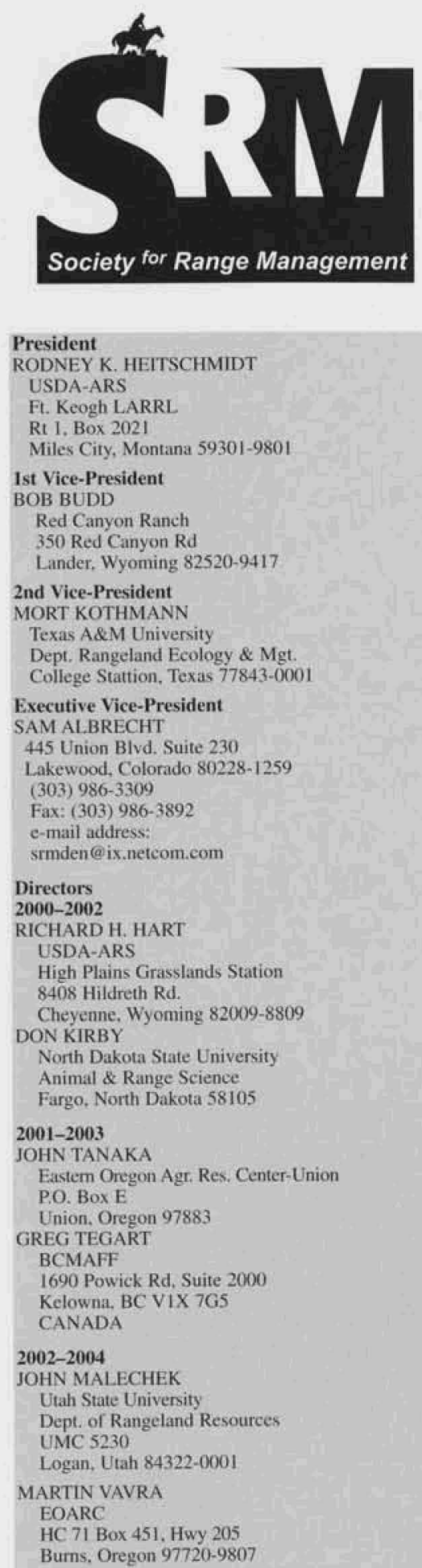

The term of office of all elected officers and directors begins in February of each year during the Society's Annual Meeting

SRM Office Staff, 445 Union Blvd., Suite 230. Lakewood. Colorado 80228: Telephone (303) 986-3309: Fax (303) 9863892: e-mail address: stmden@ix.netcom.com; home page http://srm.org

AARON BARR — Membership Services Manager SVETI.ANA GLUSHKO Office Service Assistant ANN HARRIS Director of Administration/Programs PATTY RICH - Production Editor KIRSTEN TARDY - Director of Accounting \& Sales

\section{The Society for Range Management}

The Society for Range Management founded in 1948 as the American Society of Range Management, is a nonprofit association incorporated under the laws of the State of Wyoming. It is recognized exempt from Federal income tax, as a scientific and educational organization, under the provisions of Section 501(c) (3) of the Internal Revenue Code, and also is classed as a public foundation as described in Section 509 (a) (2) of the Code. The name of the Society was changed in 1971 by amendment of the Articles of Incorporation.

The objectives for which the corporation is established are:

-to properly take care of the basic rangeland resources of soil, plants and water;

-to develop an understanding of range ecosystems and of the principles applicable to the management of range resources;

-to assist all who work with range resources to keep abreast of new findings and techniques in the science and art of range management;

-to improve the effectiveness of range management or obtain from range resources the products and values necessary for man's welfare;

-to create a public appreciation of the economic and social benefits to be obtained from the range environment;

- to promote professional development of its members.

Membership in the Society for Range Management is open to anyone engaged in or interested in any aspect of the study, management, or use of rangelands. Please contact the Executive Vice-President for details.

\section{$R a n g$ e $l$ a $n d s$}

Rangelands serves as a forum for the presentation and discussion of facts, ideas, and philosophies pertaining to the study, management, and use of rangelands and their several resources. Accordingly, all material published herein is signed and reflects the individual views of the authors and is not necessarily an official position of the Society. Manuscripts from any source-nonmembers as well as members-are welcome and will be given every consideration by the editors. Rangelands is the nontechnical counterpart of the Journal of Range Management; therefore, manuscripts and news items submitted for publication in Rangelands should be in nontechnical nature and germane to the broad field of range management. Editorial comment by an individual is also welcome and, subject to acceptance by the editor, will be published as a "Viewpoint."

\section{Contribution Policy:}

The Society for Range Management may accept donations of real and/or personal property subject to limitations set forth by State and Federal law. All donations shall be subject to management by the Executive Vice President as directed by the Board of Directors and their discretion in establishing and maintaining trust, memorials, scholarships or other types of funds. Individual endowments for designated purposes can be established according to Society policies. Gifts, bequests, legacies, devises, or donations not intended for establishing designated endowments will be deposited into the SRM Endowment Fund. Donations or request for information on Society policies can be directed to the Society for Range Management, Executive Vice President, 445 Union Blvd., Suite 230, Lakewood, Colorado 80228. We recommend that donors consult Tax Advisors in regard to any tax consideration that may result from any donation. 


\section{Volume 24 No. 1 \\ February 2002}

Published bimonthly - February. April, June, August, October, December

Copyright 2002 by the Society for Range Management

Managing Editor

KINDRA GORDON

P.O. Box 645

Speartish, South Dakota 57783

(605) $722-7699$

E-Mail: kindras@gordonresources.com

Editor/Copy Editor

GARY/JO FRASIER

7820 Stag Hollow

Loveland, Colorado 80538

(970) 663-3094

E-Mail: gfrasier@lamar.colostate.edu

Production Editor

PATTY RICH

3059A Hwy 92

Hotchkiss, Colorado 81419-9548

(970) $872-5932$

E-Mail: prich@starband.net

Book Review Editor

DAVID L. SCARNECCHIA

Dept. Natural Res. Sci.

Washington State University

Pullman, Washington 99164-6410

E-Mail: scameda@mail wsu :edu

Editorial Board

1999-2001

JAMES BRUNNER, Medford, Oregon

DAN ROBINETTE. Tucson, Arizona

MARILYN J. SAMUEL Lehigh Acres, Florid:

JAN WIEDEMANN, College Station, Texas

2000-2002

LYNN HUNTSINGER, El Cerrito, California

JOHN MITCHEI L, Fort Collins, Colorado

KIETH SEVERSON, Isle, Minnestoa

AMY SMITH. Burns, Oregon

2001-2003

DAVID BRADFORD, Paonia, Colorado

RANDEL DONGES, Dalhart, Texas

MICHAEL FRISINA, Butte, Montana

ART MEEN, Fredonia, Arizonat

INDIVIDUAL SUBSCRIPTION is by membership in the Society for Range Management

LIBRARY or other INSTITUTIONAL SUBSCRIPTIONS, on a calendar year basis, are $\$ 65.00$ in the United States, $\$ 89.00$ in all other countries. Payments from outside the

United States should be remitted in US dollars by internation-

al money order or draft on a New York bank.

BUSINESS CORRESPONDENCE, concerning subscriptions, advertising, back issues, and related matters, should be addressed to the Managing Editor, 445 Union Blvd., Suite 230. Lakewood, Colorado 80228. Phone 303-986-3309.

EDITORIAL CORRESPONDENCE, concerning manuscripts or other edited matters, should be addressed to the Technical Editor, 7820 Stag Hollow Road Loveland, Colorado 80538.

RANGELANDS (ISSN-0190-0528) is published six times yearly (February April June August, Oclober, and December) by the Society for Range Management, 445 Union December) by the Society for Range Management, 445 Union
Blvd. Suite 230, Lakewood, Colorado 80228 , Phone 303986-3309. PERIODICALS POSTAGE paid at Denver. Colorado and additional offices.

POSTMASTER: Return entire journal with address change-Address Service Requested-to Sceiety for Range Management, 445 Union Blvd., Suite 230, Lakewood, Colorado 80228

PRINTED IN THE USA

\section{Rangelands}

\section{FEATURE ARTICLES}

Landscape Attributes Of Subdivided Ranches

by John E. Mitchell, Richard L. Knight and Richard J. Camp ... 3

Maintaining Viable Farms and Ranches Adjacent to National

Forests for Future of Wildlife and Open Space

Part I: The History of the Problem

by Jack Ward Thomas and Stephanie Lynn Gripne . . . . . . . . 10

Part 2: Working Towards a Solution

by Stephanie Lynn Gripne and Jack Ward Thomas ... . . . . . 13

Aiming For Range Management Literacy

by Christine Moseley, Mark Moseley, and Seburn Pense . . . 17

The Importance of China's Nomads

by Daniel Miller . . . . . . . . . . . . . . . . . . . . . . . . . .

The African Scene

by Peter J.K. Zacharias ...................... 2

Issues Challenging Rangelands Down Under

by Andrew Ash and Mark Stafford Smith

The Future Role of Range Management Professionals:

A Canadian Perspective

by Michael Pitt and Arthur Bailey . ..................

Viewpoint: Using the Preferred Grazing System

by Marion E. Everhart . . . . . . . . . . . . . . . . . . . . 34

\section{DEPARTMENTS}

2 EVP Comments

35 Resource Roundup

38 Browsing the Literature

40 Requiescat in Pace
21 Listening to the Land

36 Interpretive Summaries

41 Book Review
40 Letters to the Editor

\section{COVER}

Our series on international range management trends conclude. See page 22. FRONT COVER: Tibetan Nomad, Tibet, P.R. China, BACK: Tibetan Nomad lady. Photos by Daniel Miller

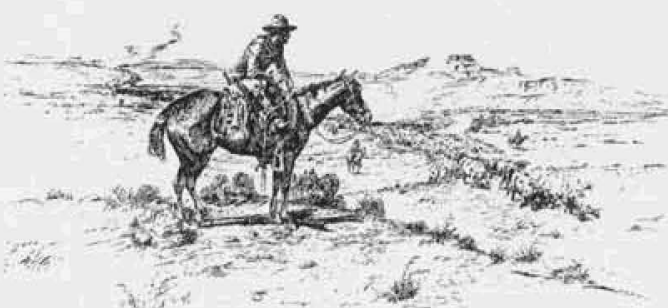




\section{EVP's Comments}

\section{Membership Gives SRM Stronger Voice}

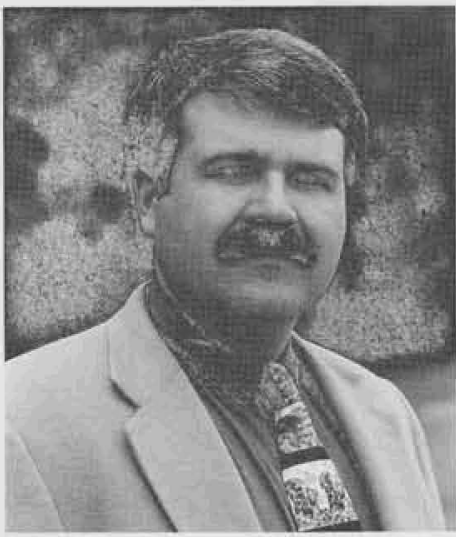

In my February Trail Boss News column, I asked each section, committee, and member to focus on membership. I want to now expand upon that theme just a little and tell you why this focus is extremely important this year.

In 2001, SRM placed a heavy emphasis on planning. We have started, and will continue, the Journey to Change. We have started, and will continue, a Strategic Plan. We have started, and will continue, to develop our Five-Year Financial Plan.

All this planning has highlighted some great opportunities for SRM. The visions and goals are now coming before the Board as projects which are going to require funding. Current funding does not allow us to begin all the projects we would like. So, this results in requiring us to now prioritize our list and see where the funding line lies.

And guess what, funding comes from members and outside revenue sources. Notice I said "and". And we are pursuing outside revenue. But a key to remember is that each new member helps us do more. Each renewing member helps us to do more.

Revenue aside, there is another reason to increase membership. The bigger the membership of SRM, the more our "voice" carries when we deal with agencies, legislatures, and other non-profits. It's pretty simple, the bigger the membership, the better job SRM leadership can do for range management.

In the last Rangelands, I talked about the commitment of the SRM leadership. Regardless of your membership type, your commitment is just as important. And I am not asking for a silent commitment. As we lay out the plans and projects for SRM in future publications, let your leaders, and let me, know what you think. Just as every vote counted in the last presidential election, every membership counts in SRM.-Samuel Albrecht, SRM Executive Vice President 


\title{
Landscape Attributes Of Subdivided Ranches
}

\section{The trend toward "ranchettes" is leaving range and forest lands fragmented and will create new challenges for livestock, wildlife and range managers.}

\author{
By John E. Mitchell, Richard L. Knight and Richard J. Camp
}

The western states have become the fastest growing region in the United States during the 1990's. Previously, people living in the West could be divided into two dissimilar groups - urban dwellers in cities and larger towns, and those residing in rural areas on farms and ranches and in small towns (Figure 1).

Today, differences between Western urban and rural areas are less distinct as a new segment of the population moves onto small acreages, commonly called "ranchettes." These small tracts of land sold for rural residences come almost exclusively from the subdivision of farms and ranches. As a result, many rural localities are experiencing rapid population growth from such demographic shifts (Riebsame 1997). These rural areas are attracting a disproportionate share of young families and col- lege graduates (Nord and Cromartie 1999).

Most notably, subdivisions fragment rangelands primarily from construction of roads and buildings. Theobald and his associates (1996) evaluated landscape change following recent subdivisions of ranches in the East River Valley above Gunnison, Colorado. They found that total road length increased by 60 percent between 1964 and 1994, with more than one-third of new road construction occurring during the last five years. The number of buildings more than doubled during the same 30-year period.

Subdivided parcels in the mountains are frequently situated in valley bottoms and on nearby mountain slopes (Figure 2). Along the foothills between the plains and montane zone of the Rocky Mountain Front Range, rural areas are similarly being subdivided for residences. However, the physiographic features of privately-owned Front Range landscapes are somewhat different than those found at higher elevations. Proximity to public lands, primarily National Parks and National Forests, is common to both situations.

Unlike $19^{\text {th }}$ Century pioneers to the region who commonly established homesites in drainages for protection from wind and storms, foothills subdivisions are repeatedly laid out on high ground overlooking surrounding landscapes. New home construction and well digging technologies, coupled with no necessity of having to care for livestock, allow today's foothills ranchette resident to place a premium upon panoramic viewscapes.

Although subdivision parcels exceeding 35 acres are widespread, many are partitioned into smaller sizes. Land val-

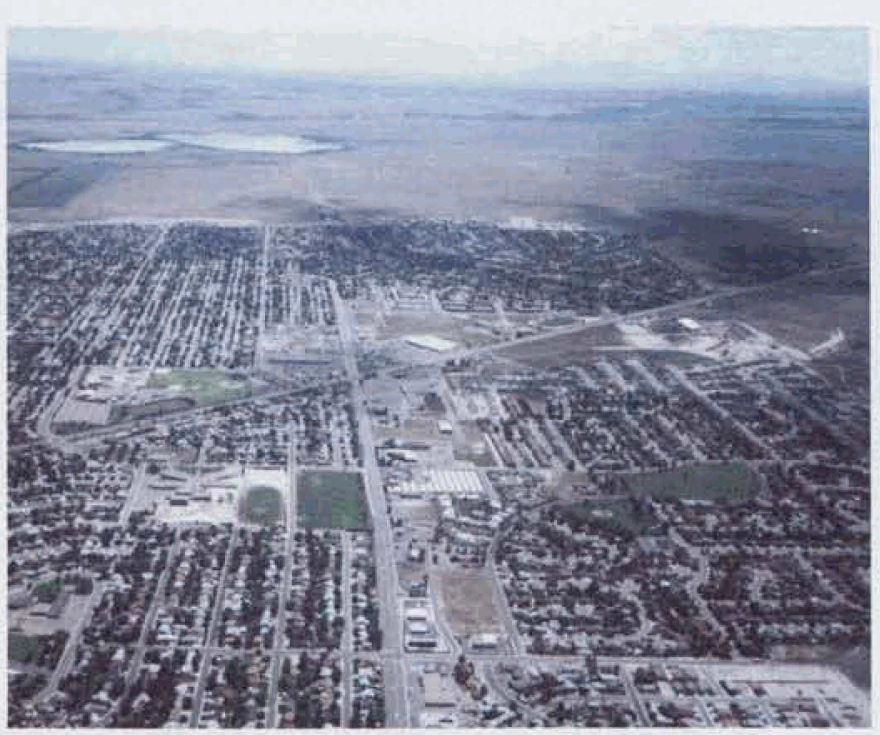

Fig. 1. Looking south over Pueblo, Colorado. The definite separation between the city and a relatively unoccupied rural landscape can be seen.

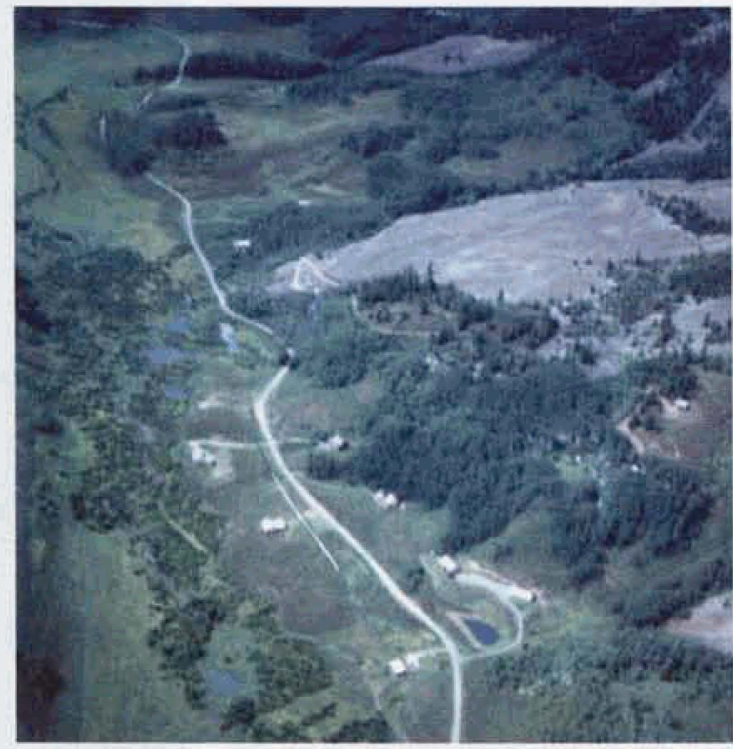

Fig. 2. Subdivided rangeland along upper Ohio Creek, Gunnison County, Colorado. 


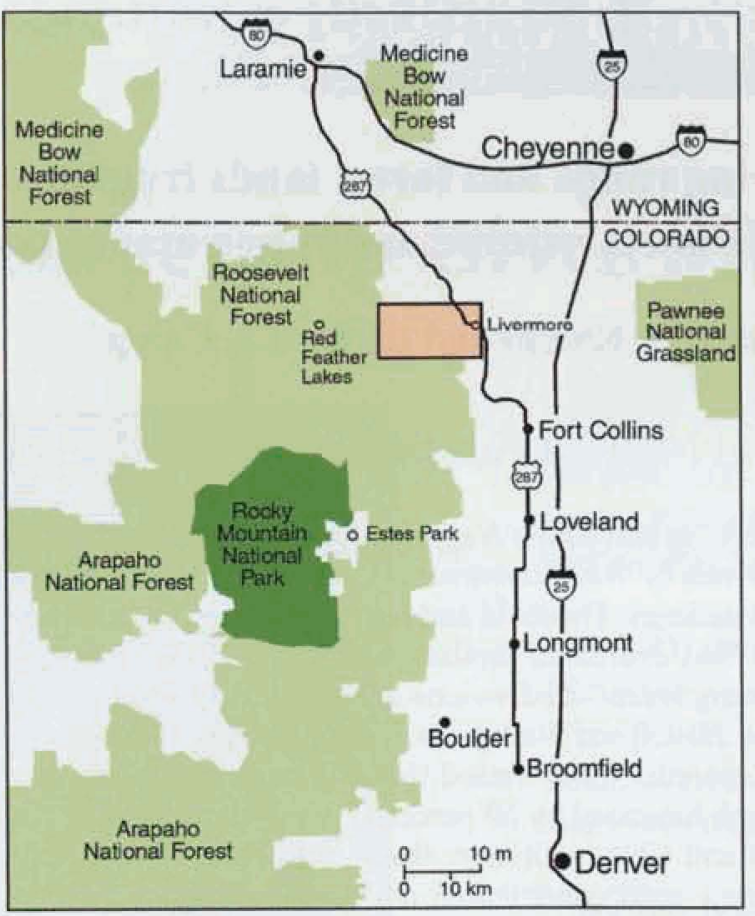

Fig. 3. Study area in Colorado Front Range foothills in vicinity of Livermore, Colorado.

ues make it more profitable to do so, even when going through local and/or state planning requirements. Callies and colleagues (1994) noted that lot sizes smaller than 5 acres spell the demise of rural land characteristics, resulting in more urban conditions on a larger rural countryside.

Increased human densities in historically rural areas may have tangible effects on landscape characteristics and, consequently, wildlife communities (Riebsame et al. 1996). Several studies have indicated that residential development of lands adjoining public lands alters wildlife communities (Odell and Knight, in press). Little is known about the exact impacts subdivisions have on rangeland ecosystems, but evidence suggests that changes in both the ecological and social landscape tend to follow development of rural areas (Theobald 1995).

Some changes in landscape parameters can be detected using aerial photographs. To describe these changes, we focused on subdivided ranches in the foothills of the Rocky Mountain Front Range in Larimer County, Colorado (Figure 3).
Vegetation along the northern Colorado Front Range is a mosaic of grassland, shrubs (primarily mountain mahogany and bitterbrush), and stands of ponderosa pine at higher elevations. Riparian areas and meadows occur along the North Fork of the Poudre River and other streams. Elevation in the area ranges from $5,600 \mathrm{ft}$. at the eastern limit to $7,800 \mathrm{ft}$. at the western limit.

The population in unincorporated Larimer County has grown rapidly over the past 25 years, rising from 26,000 to 66,000 residents between 1970 and 1999 (Larimer County data; see <http:// www.co.larimer.co.us/about/vitals.htm). As a result, landscapes neighboring the Roosevelt National Forest have become a mosaic of intact and subdivided ranches. Structures vary from small vacation cabins to large houses with outbuildings that are inhabited year-round (Figure 4).

The tendency towards larger, permanently-occupied houses corresponds with the interpretation made by Davis and associates (1994) that cities with attractive adjacent rural areas generate an outlying zone they called "exurbs", comprised of relatively wealthy ruraldwellers who commute to jobs in town.

\section{The Ranches}

For our investigation, we selected two intact ranches and two ranches that had been subdivided into small tracts ap-

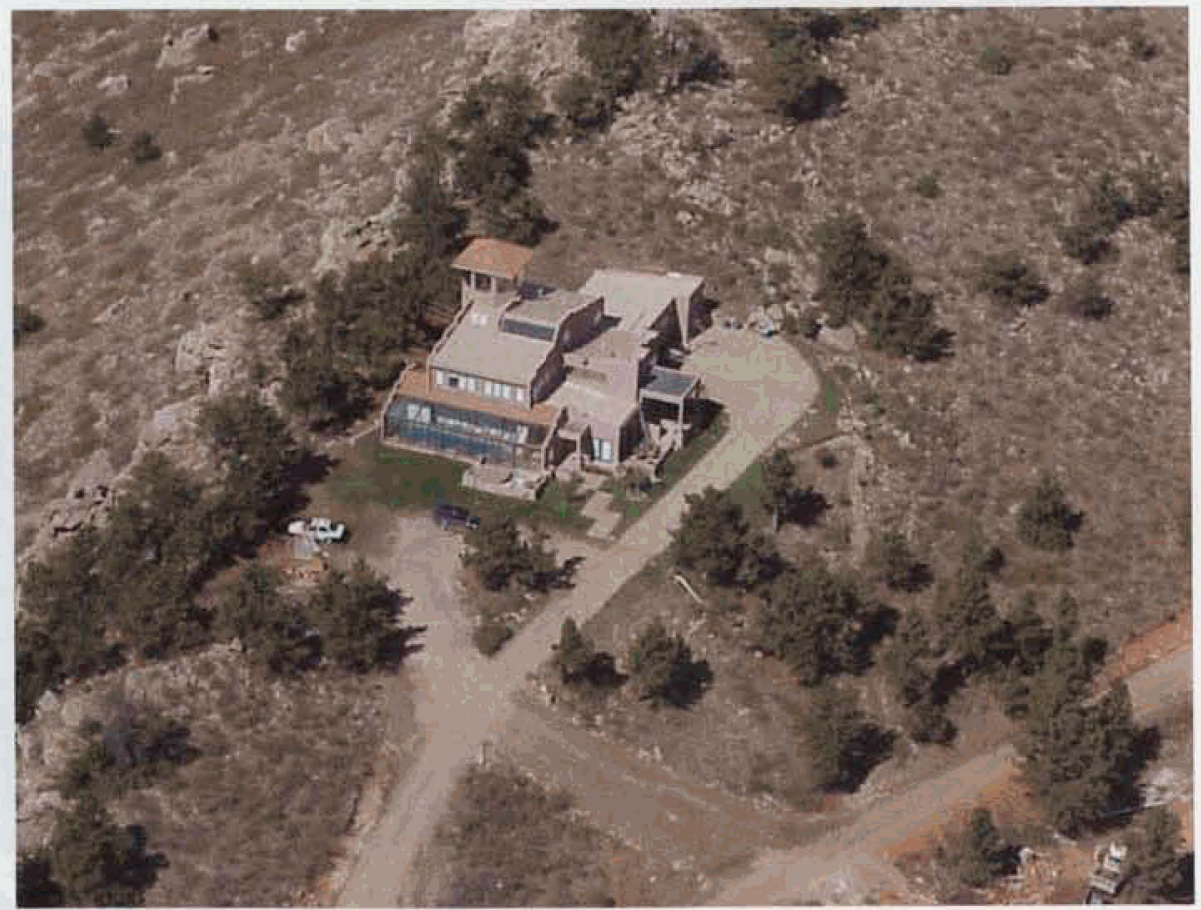

Fig. 4. Large home situated on subdivided ranch in Larimer County, Colorado. 


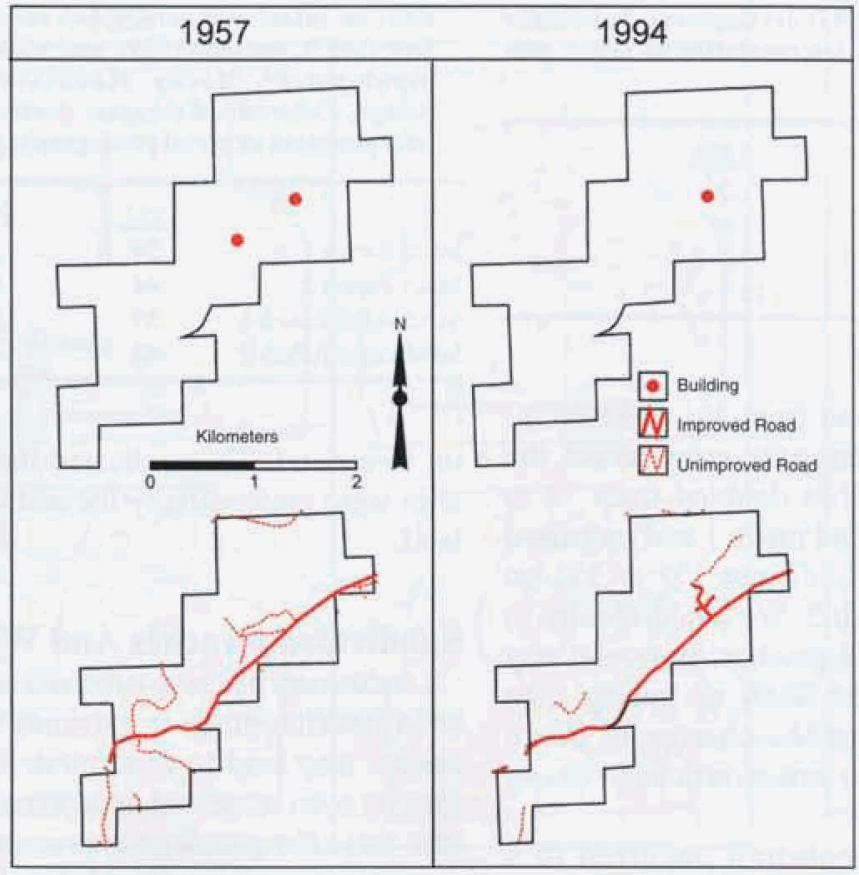

Fig. 5. Distribution of buildings and roads on intact ranch 1, Rocky Mountain Front Range, Colorado.

proximating 35 acres. We wanted to minimize total variation in landscape by limiting the sampling population to ranches with similar physiography and encompassing a contiguous area of at least two sections of land (1,280 acres). Two subdivided ranches in the Front Range foothills of northern Colorado met these criteria.

Subdivided ranch 1 began subdivision in the mid-1970's and was still undergoing active development in 1994, the last year of data acquisition. Located west of U.S. Highway 287 and south of Livermore, Colorado, its area spanned 6,450 acres. Most of the western onethird of the former ranch remained undeveloped because of steep terrain above the North Fork of the Cache la Poudre River.

Subdivided ranch 2 was platted for subdivision in the late 1960's and development began in the early 1970's. It is situated along the south side of a paved county highway connecting Livermore, Colorado with Red Feather Lakes, Colorado. The total area subdivided was approximately 8,900 acres, and had been largely developed by 1990 . Improved access roads and home sites were concentrated along the northern half of the former ranch because of steep terrain in the southern half above the Cache la Poudre River.

The two intact ranches were located within a few miles of the subdivided ranches. Elevations, physiography, and vegetation were similar to the subdivided ranches. They also possessed all the qualities that lend themselves to be valued for subdivision; i.e., access to an all-weather highway, scenery, and within commuting distance of Front Range urban centers.

Intact ranch 1 was fairly small with a contiguous area of 1,250 acres, while intact ranch 2 contained 6,930 acres, a size which more closely approximated the dimensions of the subdivided ranches.

\section{Our Evaluation}

Data were acquired from aerial photographs, provided by U.S. Department of Agriculture, Consolidated Farm Service Agency, Salt Lake City, Utah. The 1:20,000 photographs were taken in 1957 and 1994. These years were selected to acquire landscape information prior to any development activity on the subdivided ranches and after most development activity had been completed.

We suspected that subdivision of ranches would change both patch characteristics and the distributions of features such as fences and roads. We defined a landscape patch as a relatively discrete area of similar vegetation or obvious land use. Forest communities in the area were all dominated by ponderosa pine and the rangeland communities were combined into one land-use category. No land within the four ranches was being farmed, so the land cover/use categories were fairly simple (Table 1). Information on the aerial photographs were digitized into a GIS using ARC/INFO.

We were interested in how subdivision changed the density of buildings, fences, and improved roads, and if these features would increase the number of landscape patches. Preliminary aerial photo interpretation showed that we could not identify the presence of fences, which were then dropped as a variable.

Unimproved ranch roads were not considered as barriers because of their narrowness and the presence of native

Table 1. List of features used for assessing patch characteristics resulting from subdividing intact ranches, Rocky Mountain Front Range, Colorado.

\begin{tabular}{ll}
\hline \hline Feature & Categories \\
$\begin{array}{l}\text { Land Use } \\
\text { Roads }\end{array}$ & $\begin{array}{l}\text { Forest, rangeland, riparian, water. } \\
\text { Improved (paved/gravel with } \\
\text { shoulders), } \\
\text { unimproved (dirt with no } \\
\text { shoulders). }\end{array}$ \\
Structures & All (houses, barns, sheds, etc.). \\
\hline
\end{tabular}

vegetation between the tracks. Wild and domestic ungulates tend to cross these roads as if they do not exist. Likewise, vehicular traffic is slow moving, light and sporadic, which minimizes encounters with wild animals. Road density was expressed in miles per section (640 acres).

We also wanted to find out whether the two subdivisions were more likely to fragment rangeland or forest land in an area where the ponderosa pine zone met the high plains. 
Table 2. Building densities per section ( 640 ac.) on intact and subdivided ranches, Rocky Mountain Front Range, Colorado, before (1957), during (1983), and after (1994) development. Subdivided ranch 2 is not yet completely developed. Estimates derived from interpretation of aerial photographs.

\begin{tabular}{llcr}
\hline \hline & & $\frac{1957}{1.0}$ & $\frac{1994}{5}$ \\
Intact Ranch 1 & $(1,250 \mathrm{ac})$. & .5 & .6 \\
Intact Ranch 2 & $(6,930 \mathrm{ac})$. & .6 & 5.2 \\
Subdivided Ranch 1 & $(6,450 \mathrm{ac})$. & .8 & 13.7 \\
\hline Subdivided Ranch 2 & $(8,900 \mathrm{ac})$. & & \\
\hline
\end{tabular}

Not surprisingly, subdividing a ranch into smaller parcels substantially increased the density of both buildings and improved roads. On average, buildings on both of the intact ranches were each surrounded by nearly 2 sections of land $(1,280$ acres) throughout the sampling periods of 1957 and 1994 (Figures 5 and 6). The two subdivided ranches had a building density similar to the intact ranches prior to subdivision (Table 2). Housing density was 17.5 times greater after subdivision on the area that had been almost completely developed (subdivided ranch 2) and 8.5 times greater on the area that was somewhat less developed (subdivided ranch 1) (Figures 7 and 8 ).

Road density before subdivision was about $0.4 \mathrm{mi}$. per section ( 640 acres) for all ranches except the smaller intact ranch (Table 3 ). Its road density was three times the other ranches because the state highway between Livermore and Redfeather Lakes ran through its long axis and the ranch was relatively small. If U.S. Highway 287 and the Red Feather Lakes highway were not included in our analyses, all four ranches had an improved road density of zero in 1957. Road density on the two intact ranches remained fairly constant in absolute terms throughout the two sampling periods.

On subdivided ranches 1 and 2, improved road density increased by more than eight times after subdivision (Table 3). Road construction had been completed on subdivided ranch 1 , even though a number of available land parcels were not yet occupied in 1994. Assuming an average fenceline-to-fenceline improved road width of $50 \mathrm{ft}$., roads comprised approximately 3 to 5 percent of the total area on subdivided ranches.

Between 1957 and 1994, the number of patches decreased from 39 to 33 on intact ranch 1 and from 101 to 81 on intact ranch 2. During the same period, the number of patches doubled from 78 to 155 on subdivided ranch 1 and increased more then fourfold from 133 to 571 on subdivided ranch 2 . We had difficulty in discerning some patches; however, any errors were most likely no greater than the variation in the change in patch numbers on the intact ranches-about 15-20 percent.

Patch fragmentation occurred to a much greater extent on rangeland than it did on forested areas (Table 4). There was twice the number of patches on rangelands following subdivision than

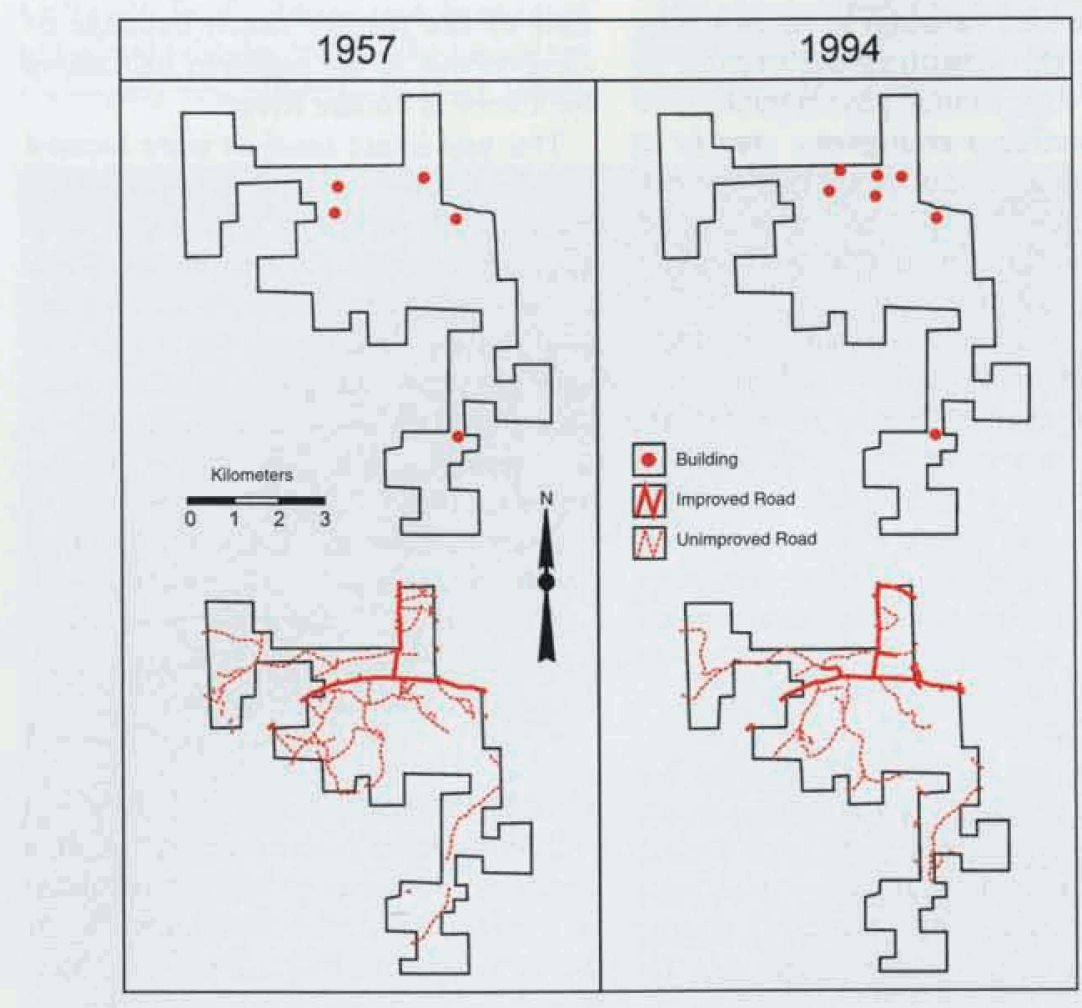

Fig. 6. Distribution of buildings and roads on intact ranch 2, Rocky Mountain Front Range, Colorado.
Table 3. Improved road densities (mi. per section) on intact and subdivided ranches before (1957), during (1983), and after (1994) development, Rocky Mountain Front Range, Colorado. Estimates derived from interpretation of aerial photographs.

\begin{tabular}{lrr}
\hline \hline & 1957 & \\
\cline { 3 - 3 } Intact Ranch 1 & 1.24 & 1.594 \\
Intact Ranch 2 & .44 & .64 \\
Subdivided Ranch 1 & .39 & 3.38 \\
Subdivided Ranch 2 & .44 & 5.71 \\
\hline
\end{tabular}

on forestland. This indicated that home sites were preferentially located on open land.

\section{Subdivided Ranches And Wildlife}

Landowners planning subdivisions situated in foothills settings in proximity to urban centers may tend to concentrate building sites on open rangeland or scattered timber sites that offer grandiose viewscapes. Such a strategy explains the higher level of rangeland fragmentation we found in comparison to forest fragmentation.

People purchasing small acreage tracts in montane areas farther removed from 


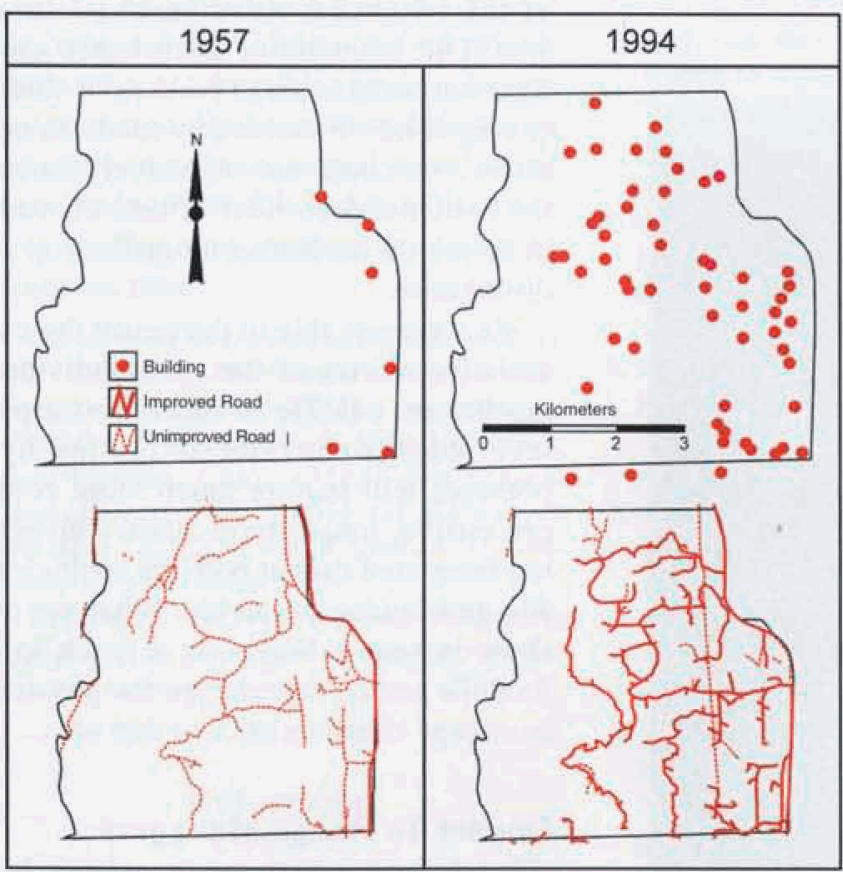

Fig. 7. Distribution of buildings and roads on subdivided ranch 1, Rocky Mountain Front Range, Colorado.

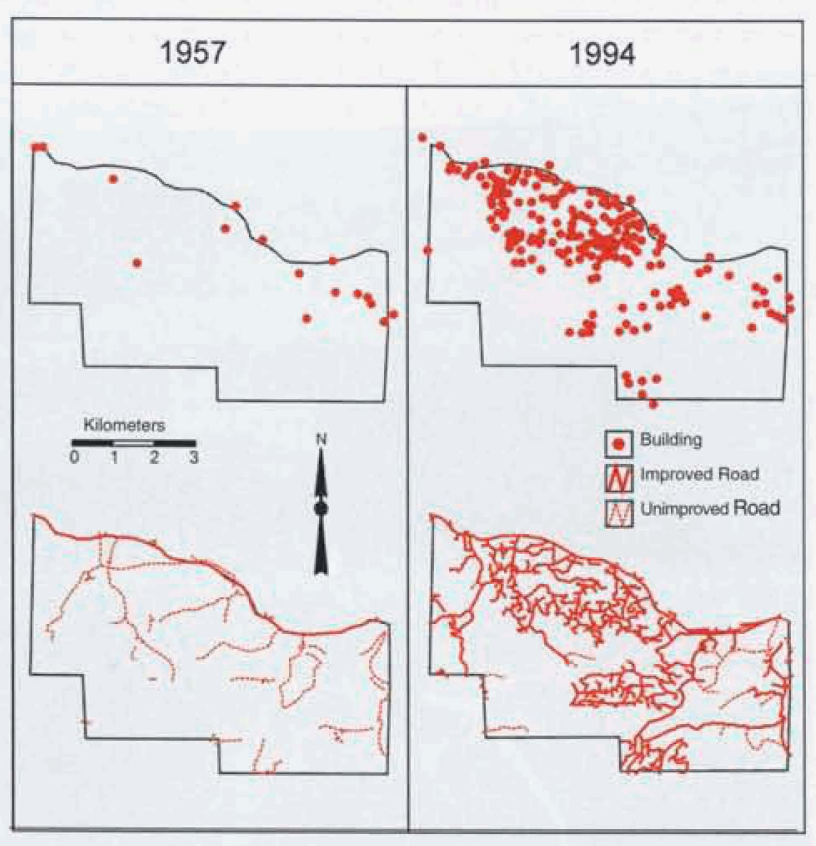

Fig. 8. Distribution of buildings and roads on subdivided ranch 2, Rocky Mountain Front Range, Colorado. urban centers apparently are more apt to desire forested cover types that hide their houses from passersby (Figure 9). If is not known if the size of a rural house, the size of individual tracts, or other factors are related to residences' position in the landscape.

Table 4. Total number of rangeland and forested land patches on two intact and two subdivided ranches before (1957) and after (1994) development, Rocky Mountain Front Range, Colorado.

\begin{tabular}{lrr}
\hline \hline Rangeland & $\frac{1957}{35}$ & $\frac{1994}{49}$ \\
Intact Ranches & 55 & 411 \\
Subdivided Ranches & & \\
Forested land & $\frac{1957}{23}$ & $\frac{1994}{19}$ \\
Intact Ranches & 107 & 206 \\
\hline Subdivided Ranches & 107 \\
\hline
\end{tabular}

Subdivision of ranches into exurban developments has been shown to cause an increase in free-ranging dog and cat populations, vehicular traffic, illumination from yard lights, nonnative plants, and the number of people present on the land (Knight et al. 1995). Each of these changes creates disturbance zones around houses and along roads that can diminish wildlife populations (Odell and Knight, in press). Rural dog and cat populations result in increased predation on small mammals and songbirds, and even some larger mammals like weasels and deer fawn (see references in Jurek 1994). Effects of yard lights on wildlife are not adequately understood, but it appears that bright lights may alter the movement of some species such as mountain lions (Beier 1995).

Roads accessing subdivided parcels are graded and often well-traveled (Figure 10). Hence, they can affect wildlife in a variety of ways. Some species that do not do well in edge habitat or are sensitive to humans, are unwilling to cross roads. Others seek roads for heat or food. Nocturnal species tend to avoid lights (Schonewald-Cox and Buechner 1993). For some big game species, the disturbance impact is correlated with the intensity of road use and the openness of vegetation (Perry and Overly 1976).

Rural subdivisions result in an increased number of people, and human activity is one of the principal ways that wildlife is disturbed (references in Knight and Gutzwiller 1995). Not all wildlife species are equally sensitivity to human presence. Some species tend to avoid humans while others are attracted to them.

For example, Odell and Knight (in press) recorded decreases of black-headed grosebeaks, blue-gray gnatcatchers and orange-crowned warblers and increases of black-billed magpies, brownheaded cowbirds, and European starlings numbers with increasing housing development. They also found elevated populations of dogs and cats and fewer foxes and coyotes near exurban homes in Colorado.

The distribution of rural residences on the two subdivided ranches we examined appeared to be somewhat clustered. The aggregated nature of the improved road networks and building distributions are a result of terrain considerations. Theobald and colleagues (1997) have demonstrated that, when rural subdivisions are spatially clustered, the proportion of land that would disturb wildlife is considerably reduced.

The circles depicting buildings in figures 5 through 8 represent a disturbance zone with a $100-\mathrm{m}$ radius (Odell and Knight, in press). Assuming this sized disturbance zone for all buildings leads to a total disturbance area of about 1,900 acres for the subdivided ranches in 1994. We estimate that roads add 900 acres of disturbance area. Thus, the total disturbance caused by homesites and roads comes to approximately one-fifth 


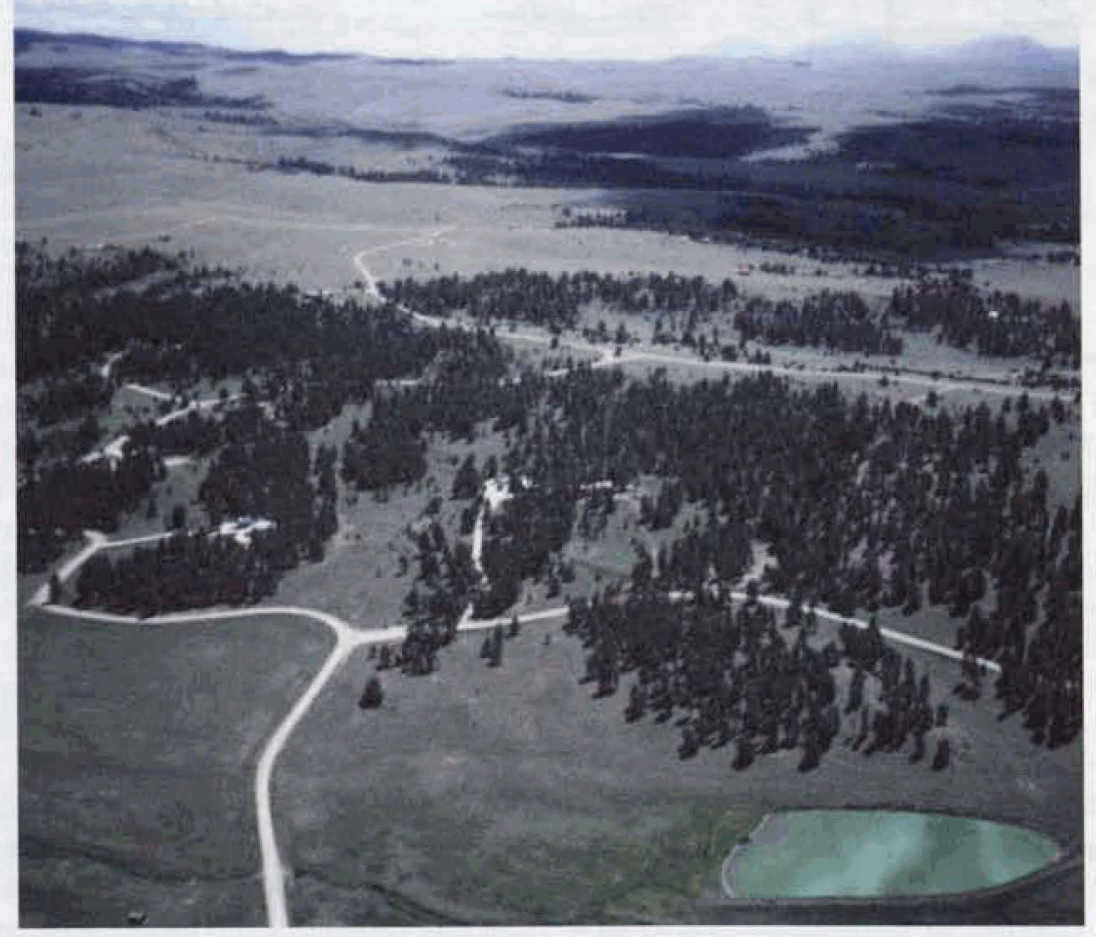

Fig. 9. Subdivided land in the Wet Mountain Valley, Colorado. Note the location of homes within ponderosa pine patches.

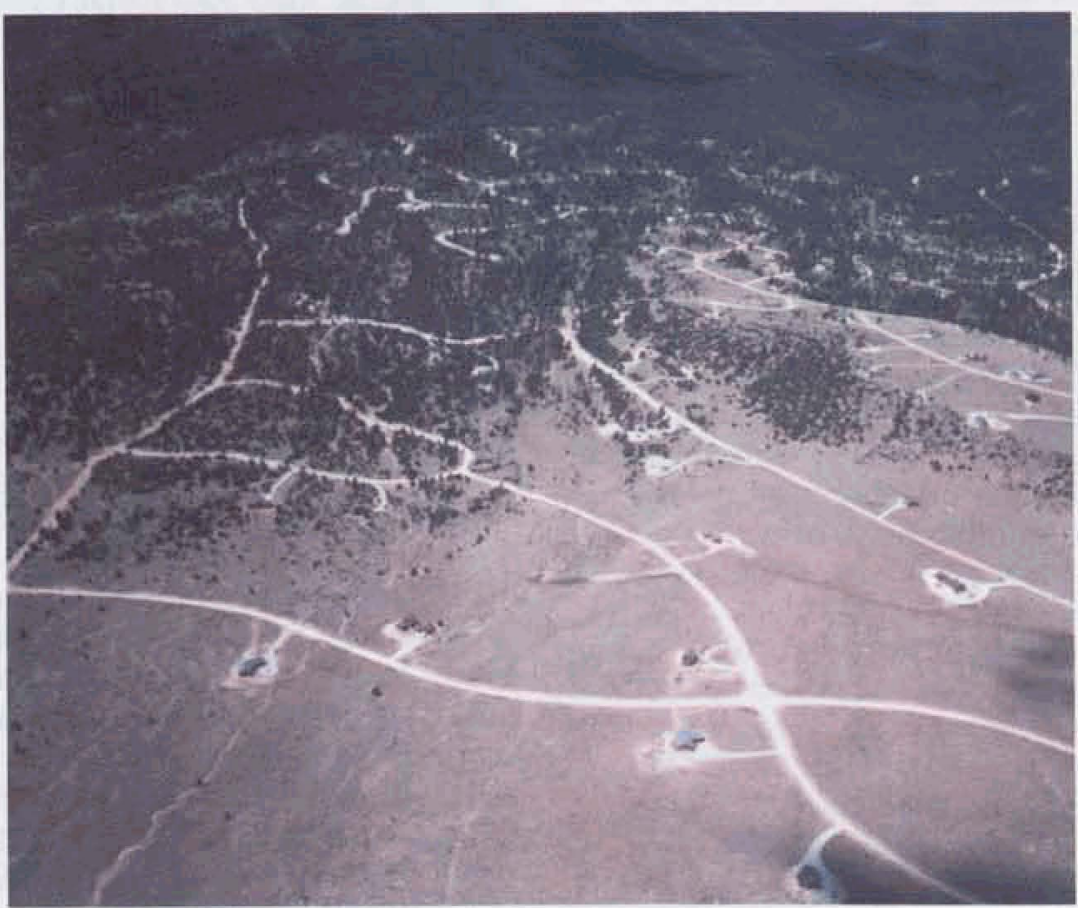

Fig. 10. Road network on subdivided ranch in southern Colorado. of the two subdivided ranches' total area. Our estimate of disturbance area does not include small patches of forest or rangeland surrounded by roads. In addition, we could not objectively assess the barrier and corridor effects of roads in terms of its further contribution to disturbance.

We were not able to document the cumulative effects of the two subdivided ranches on wildlife or other landscapelevel ecosystem effects. Testing hypotheses will require much more comprehensive, longer term studies involving integrated data at both the ecological site and landscape levels. What we do show is how subdividing a ranch in a foothills setting can change the physical landscape characteristics of that area.

\section{Impact To Range Managers}

Subdivision of private rangelands has the potential to affect nearby public and private rangeland managers in a number of ways. Subdivision can result in increased populations of nonnative weedy species as a result of landscaping, vegetation and soil disturbance during building and road construction, and overgrazing on small horse pastures (Knight and Clark 1998). These actions increase the potential for nonnative species and noxious weed invasion of adjacent rangelands and forests.

Additionally, vegetation management objectives that include the use of prescribed fire or managed wildfire may be limited due to the danger posed to new housing developments.

Subdivision of rangelands adjacent to public lands creates resource management issues as well. One of the attractions of rural subdivisions is private access to public lands. The overall effects of larger populations living along the borders of public lands, while still uncertain, are slowly being recognized.

One consequence of these changing residence patterns, for example, has been a cross-boundary demand for water from public lands that can impact management plans for wildlife and livestock grazing (Mitchell and Wallace 1998). More limited access to public lands by non-residents may result in increased usage of remaining access areas, leading to issues of overuse (Theobald 1995). 
Lastly, wildlife management may also be impacted by subdivision of private lands adjacent to public lands. Changes in vegetation composition and landscape structure may limit animal travel corridors, reduce suitable habitat for sensitive species, and increase predation by domestic pets.

The authors are, respectively, Rangeland Scientist, Rocky Mountain Research Station, Fort Collins, Colo. 80526; Professor of Wildlife Biology, Colorado State University, Fort Collins, Colo. 80523; and Project Specialist, USGS Biological Resources Division, Kilauea Field Station, Hawaii National Park, Hawaii 96718.

This paper was peer reviewed. We greatly appreciate the thoughtful comments provided by one anonymous reviewer.

\section{References}

Beier, P. 1995. Dispersal of juvenile cougars in fragmented habitat. J. Wildlife Manage. 59:228-237.

Callies, D.L., R.H. Freilich, and T.E. Roberts. 1994. Cases and materials on land use. 2nd ed. West Publishing Co., St. Paul, Minnesota. 747 pp.

Davis, J.S., A.C. Nelson and K.J. Dueker. 1994. The new 'burbs': the exurbs and their implications for planning policy. J. Amer. Planning Assoc. 60:45-59.
Jurek, R. M. 1994. A bibliography of feral, stray, and free-roaming domestic cats in relation to wildlife conservation. Nongame Bird and Mammal Program Report No. 94-5. California Department of Fish and Game, Sacramento, California.

Knight, R. L. and K. J. Gutzwiller (ed.). 1995. Wildlife and recreationists: coexistence through management and research. Island Press, Covelo, California. 372 pp.

Knight, R. L., G. N. Wallace, and W. E. Riebsame. 1995. Ranching the view: subdivisions versus agriculture. Conserv. Biol. 9:459-461.

Knight, R.L. and T.W. Clark. 1998. Boundaries between public and private lands: defining obstacles, finding solutions, p.175-191. In: R.L. Knight and P.B. Landres (ed.), Stewardship across boundaries. Island Press, Washington, D.C.

Mitchell, J.E. and G.W. Wallace. 1998. Managing grazing and recreation across boundaries in the Big Cimarron watershed, p.217-236. In: R.L. Knight and P.B. Landres (ed.), Stewardship across boundaries. Island Press, Washington, D.C.

Nord, M. and J. Cromartie. 1999. Rural areas attract young families and college graduates. Rural Conditions and Trends 9(2):28-34.

Odell, E.A. and R.L. Knight. Wildlife communities and exurban development in Pitkin County, Colorado. Conserv. Biol., in press.
Perry, C. and R. Overly. 1976. Impact of roads on big game distribution in portions of the Blue Mountains of Washington, p.62-68. In: J.M. Peek (ed.), Proceedings of the elk-logging-roads symposium. Forest, Wildlife and Range Experiment Station, University of Idaho, Moscow, Idaho.

Riebsame, W.E., H. Gosnell, and D.M. Theobald. 1996. Land use and landscape change in the Colorado mountains, I: Theory, scale, and pattern. Mountain Research and Development 16:395-405.

Riebsame, W.E. 1997. Atlas of the New West: Portrait of a changing nation. W.W. Norton Co., New York. 192 pp.

Schonewald-Cox, C. and M. Buechner. 1993. Park protection and public roads, p.373-395. In: P.L. Fiedler and S.K. Jain (ed.), Conservation Biology. Chapman and Hall, New York, NY.

Theobald, D.M. 1995. Morphology and effects of mountain land use change in Colorado: A multi-scale landscape analysis. PhD. Dissertation. University of Colorado, Boulder. 243 pp.

Theobald, D. M., H. Gosnell, and W. E. Riebsame. 1996. Land use and landscape change in the Colorado mountains, II: A case study of the East River Valley. Mountain Research and Development 16:407-418.

Theobald, D.M., J.R. Miller, and N.T. Hobbs. 1997. Estimating the cumulative effects of development on wildlife habitat. Landscape and Urban Planning 39:25-36. 


\title{
Maintaining Viable Farms and Ranches Adjacent to National Forests for Future of Wildlife and Open Space
}

\section{Part 1: The History of The Problem}

\author{
By Jack Ward Thomas and Stephanie Lynn Gripne
}

A lthough some credit Will Rogers, famous author and humorist Mark Twain is most often noted for giving the following investment advice to a young man "Buy land-they ain't making any more of it." That was sound wisdom then, and it is sound wisdom now.

But, he didn't know the half of it. As population and per capita income simultaneously increased and land available for development decreased, the demand and price for land has increased faster than most of us can believe. Consequently, the face of the American West is rapidly changing as suburbs, "ranchettes," and hobby ranches spread across the landscape.

No matter how we twist and turn, we cannot help but believe that those who care about the changing character of the West are on the cusp of a crisis that could, over the next several decades, dramatically and negatively impact everything from open space, farms, and ranches, to wildlife, fisheries, soils, plants, and watersheds. Must this happen? Probably, but most of these effects can be dampened.

While development and loss of wildlife habitat and open space is a question of more general concern, we focus our attention on social and ecological issues related to the interface between private ranchlands and public lands. Given the experience of the senior author, (10 years with a state fish and wildlife department and 30 years in the Forest Service-27 years as a research scientist dealing with range and wildlife issues and 3 years as Chief) we further confine our discussion to the interface between private ranchlands and national forests.

Likewise, while the habitat of hundreds of species of wildlife are potentially at stake, we concentrate our dis- cussion on mule deer and elk since these are species of great public interest for both hunting and viewing.

We examine the interface between private ranchlands and national forests in two parts. In Part 1, we provide a brief narrative and history about the interactions between these land ownerships as they affect both economic and ecological relationships, specifically mule deer and elk migration. In Part 2, we discuss methods of social/political adjustment to produce the radical middle "win-winwin" outcomes among ranchers, conservationists, and wildlife in the New West.

\section{Elk, Mule Deer, and the Interface}

How are elk and mule deer affected by the interface between ranches and national forests? Every fall, as snow accumulates in the high country of the national forests, elk and mule deer must move down onto their ancestral wintering grounds to survive. In the recent past, Euro-Americans arrived upon the scene and altered these wintering grounds to meet their needs and those of their livestock.

Barbed wire fences now cross migration routes from the high country to wintering grounds. When the deer and elk arrive on wintering grounds, they commonly find only stubble left by the livestock on the south and west slopes of foothills that are blown free of snow, or the snow is melted by the sun. There is also only stubble on the meadows where the rancher raises hay and stacks it for winter-feeding of livestock. As the snow deepens and the temperatures drop, more elk and mule deer appear on the wintering grounds. No matter their physical condition when they arrive, they have begun to starve. It is always a question of which will come first, death or spring.

The elk jump the rancher's fences when they are calm. They run through fences when excited. And, seemingly, sooner or later, they inevitably get excited. The mule deer jump the fences. But, as the snow deepens and their physical condition deteriorates, more fail to clear the fences and end up hanging from the tangled top two wires.

Finding little but stubble on which to feed, they gradually overcome fear and eagerly share hay or other feed distributed by the rancher to livestock. The rancher ordinarily does not complain at least vociferously-accepting that, after all, the deer and elk were there first and most ranchers love the wild things as they love their land. But, the wintering deer and elk are not evenly distributed across the private ranches that border the national forests and some ranchers suffer the negative impacts of wintertime ungulate wildlife residents far in excess of their neighbors and receive little or no compensation.

A complaint to the Forest Service (FS) falls upon sympathetic ears but engenders no help. The animals are not on national forests and the wildlife belongs to

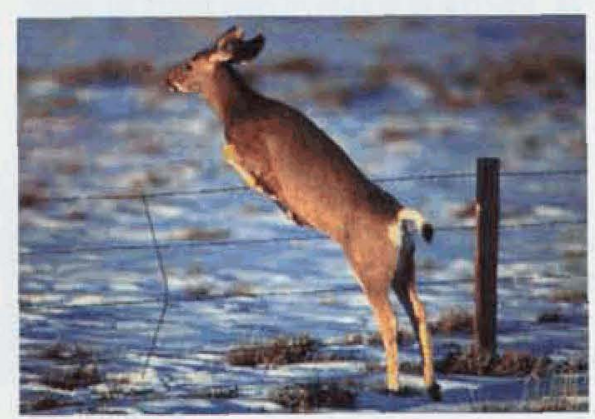

Jumping fence is just one small adjustment mule deer have had to make as the land becomes increasingly fragmented (Photo courtesy of Steven Holt). 
the State who has jurisdiction over their management. A call to the state wildlife agency will usually produce a visit or visits from a biologist or law enforcement officer who will do what they can to alleviate the problem. In some states this takes the form of some payment for "damage," which are commonly token in nature.

Sometimes harassment will be undertaken to force the animals back onto public land or to disperse them more widely. The relief from such actions is usually fleeting at best and places increased stress on the animals at the very time when their energy reserves are being depleted.

Both the aggravation and costs to the rancher, which build along with increased numbers of deer and elk - and keeps on year after year - combines with other factors to whittle away at the resolve to continue ranching. Often, that is simply the way it is. But, does it have to be that way? Is there a better way - a middle ground, a path not yet explored?

\section{The Public and Private Interface}

The West faces unique land ownership issues. In fact, a property map of the West shows a glaringly obvious mixture of public and private land. However, these lands are not only linked by their proximity on the landscape, they are inextricably linked by over a century of intertwined social and economic considerations.

We refer to the boundary of private ranchlands and national forests as the interface and are interested in this region because no other area offers as much potential to conserve wildlife habitat and open space, and no other areas are at greater risk. While this interface has provided critical wildlife habitat and open space in the past, this may not be the case for long since private lands are also the most highly sought after lands for development.

No treatise on land use in the West would be complete without consideration of the dynamics of management related to the interface between private and public land. Any effort to define and address land use in the "New West" that ignores this obvious, but poorly under- stood interface, with all of its ramifications, is no more than an academic exercise.

Farmers and, particularly, ranchers historically have played a critical role in what goes the interface. Fortunately, for those concerned about the loss of open space and wildlife, most private landowners continue to play this role.

Author Ivan Doig said that while most of us live on the land there are those who are of the land-rooted there as surely as the trees and bunch grasses. Those "of the land" have maintained their way of life- even over generations -when it would make more economic sense to sell out to land speculators and subdividers. The relatively undeveloped state of the land was assured by their determination to maintain a way of life and hang onto the land they held in trust.

These ranchers and farmers can maintain that stubborn attachment to the land only so long as their operations are at least marginally economically viable. The maintenance of anything approaching the present state of the interface between private ranchlands and national forests depends on the economic and social viability of both family owned and corporate farms and ranches. Clearly, when those farms and ranches are no longer economically and socially viable, the siren call of the subdividers and developers will grow ever more seductively sweet.

\section{National Forests and Grazing History}

Wherever there are large blocks of federal lands managed by the Forest Serive (FS) and the Bureau of Land Management (BLM), there will also be private ranches adjoining these lands. Owners of these adjacent ranches typically lease grazing rights from the federal government. Grazing privileges on national forests have been associated with these ranches for nearly a century. Hence, the national forests are part and parcel of the ranching operation and a well-established part of local cultures.

One of the FS's first tasks of the in the early 1900 's was to bring unrestricted grazing under regulation, impose reasonable fees for that grazing (Congress now sets the fees), and gain political support from grazing interests for management actions necessary to begin to recover overgrazed ranges and to reduce conflicts between ranchers. This was accomplished by coupling grazing permits for the national forests with ranches (i.e. base property) that abutted the national forests. Over the years, it became customary for these grazing permits to be transferred to new owners along with the base property to which they were connected.

The intent was to promote social and economic stability for local areas in keeping with the instructions from Secretaries of Agriculture Hitchcock and Wilson (1901 and 1905). More to the point, Gifford Pinchot, the first Chief of the FS, clearly understood that it was essential to "cut a deal" with ranchers using forest reserves if the forest reserves were to remain in existence.

Such a long-standing arrangement, spanning nearly 100 years, cannot and should not be casually disregarded legally, economically, socially, or ethically. This arrangement has not precluded changes in permitted livestock numbers, installation of grazing systems, water developments, or other requirements for continuing improvements related to the grazing operations. Such changes became routine over the past century and are ongoing.

The next significant piece of legislation relating to rangelands was the Multiple-Use Sustained Yield Act of 1960. The Multiple-Use Sustained Yield Act Stated, "It is the policy of Congress that the National Forests are established and shall be administered for outdoor recreation, range, timber, watershed, and wildlife and fish purposes..." Range was and is interpreted as inclusive of livestock grazing; hence livestock grazing on national forests was again validated by the law.

More recently ecosystem management, a mandate adopted by the FS, provides a new framework to examine the interactions of the interface between private ranchlands and national forests. Ecosystem management, in its most simple definition, is nothing more than treating ecosystems as to maintain sustainability ecologically, economically, 
and socially. In fact, some managers would say that ecosystem management is more about people than anything else. Not surprisingly, implementation of the concepts of ecosystem management seems more limited by social, economic, and political factors than by any lack of scientific information on ecological function.

\section{Ecosystem Management - The Latent Phase}

A full examination of the interactions of the management of the national forests and adjacent private ranchlands is an appropriate aspect of the rather recently adopted (1991) ecosystem management mandate for the National Forests. Ecosystem management has been defined as being inclusive of human needs and desires and takes place within the framework of laws, culture, and agreements. Furthermore, this approach requires considerations of broader (i.e., across political boundaries) scales.

In most cases the national forests are mountainous in landform while adjacent private ranchlands are at lower elevations with more gentle terrain, better watered, and have higher ecological levels of productivity. Taken together, the ranching operation that involves grazing on national forests is more apt to be a viable economic enterprise than the private ranchlands would be standing alone. Hence, an economically viable ranch is much less vulnerable to the enticements of conversion to subdivision.
The recognized challenge of implementing ecosystem management include, in what we consider their order of importance: public confidence, scales of time and space (this is where cross boundary consideration come to bear), transfer of information, and uncertainty. All of these factors can and are (knowingly or unknowingly) addressed by successful collaborative groups.

One recipe for achieving success collaborating in natural resources management is as follows:

1. Obtain and synthesize high quality information.

2. Recruit knowledgeable people representing stakeholders at the appropriate geographic scale.

3. Provide opportunities to interact and explore and provide incentives to find solutions.

4. Enable solution implementation so as to facilitate mobilization of resources, sharing ownership, adaptive adjustments and ability to change values as knowledge increases.

5. Mix items 1-4, make sure adequate resources are available, and then, stay out of the way.

\section{Collaboration - Back to the Future}

Barbara Gray defines collaboration as "the pooling of resources by multiple stakeholders to solve a set of problems." Collaboration is becoming more popular as a means for solving problems along the interface between private lands and the national forests. However, collabora tion is not a panacea. Sometimes the magic works and sometimes it doesn't.

One of the most challenging aspects of collaboration is doing so within the boundaries of the laws. Agencies like the BLM and FS must follow the applicable laws and often times are the managers responsible for implementing decisions. Therefore, inclusion of the agencies who can put the legal sideboards on a collaborative decision making process is needed from the very beginning, if the collaboration is to be successful.

Although collaboration is a long-term high investment process, the alternative is to live with the consequences of blind adherence to existing processes driven by government regulations and regulators that has been inevitably plagued by conflict.

In Part 1, we have defined the private ranchland and national forest interface, illustrated how this interface affects mule deer and elk, and demonstrated the long ecological and sociological history of the private ranchland and national forest interface. In Part 2 (found on page 13), we discuss the current state of the private ranchland and national forest interface and how we can use ecosystem management to work towards the radical center to support both wildlife and open space.

Jack Ward Thomas and Stephanie Lynn Gripne are involved with the Boone and Crockett Wildlife Conservation Program through the University of Montana at Missoula. 


\title{
Part 2: Working Towards A Solution
}

\author{
By Stephanie Lynn Gripne and Jack Ward Thomas
}

I n Part 1 (found on pages 10), we introduced the private ranchland and national forest interface, provided a historical context for the interface, and introduced ecosystem management as the potential vehicle for working towards the radical center for "win-win-win" solutions. Following in Part 2, we explore the present state of the interface more fully and discuss potential solutions for maintaining wildlife habitat and open space in the urban interface.

The interface between private ranchlands and national forests are characterized by three primary factors: 1) increased densities of people, 2 ) increased economic activities, which depend on public lands, and 3) significant changes in ecological conditions.

Increasing societal affluence with the booming economy since World War II has made lands adjacent to the national forests evermore attractive and feasible for development. Not only is the interface ripe for human occupancy, it is also ripe for development of commercial activities such as ski-areas, airports, resorts, dude ranches etc.

However, these trends in population density with subdivisions and associated development on the private ranchland portion of the interface can have significant ecological consequences. Plants, wildlife, water, soil, fire, and wind do not recognize political boundaries. Changes in plant communities and wildlife habitat caused by roads, traffic, introduction of nonnative plants and animals, and loss of deer and elk habitat and their associated predators have become some of the most pressing conservation concerns in those areas.

These alterations threaten ecological integrity and function of adjacent national forests, which are commonly at higher elevations, where deer and elk spend spring, summer, and fall. When snow lies deep in the winter, deer and elk are forced to lower elevation private lands to winter. Maintaining ranches adjacent to the national forests is one way to insure that the landscape that now wonderfully support migratory deer and elk does not fragment and is why the maintenance of viable farms and ranches that provides wildlife habitat and open space across boundaries is so critical.

\section{Sweetening The Pot-Incentives to Private Landowners}

Providing public access to wildlife on private land, regardless of the purpose, is another mechanism that results in wildlife financially benefiting private landowners. Some examples of this benefit have included state payments for wildlife damage, direct leasing of hunting privileges in a free market atmosphere, and payments from the state for accepting some number of hunters which is a hybrid system where the landowner is issued "tags" and the number of hunters are chosen by the state.

Approaches differ dramatically from state to state. For example, Texas hunters and landowners negotiate in essentially a free market situation. Conversely, in Wyoming, a suggestion that landowners be issued a limited number tags where they could select the hunter (i.e., individuals willing to pay for a guided hunt) in return for accepting a number of hunters to be chosen by the state set off a firestorm of controversy. This brawl was, and is, laced with overtones of class warfare.

Because ownership of resident wildlife resides with the states, individual states have the right to choose different approaches to achieve the desired goal of allowing landowners to profit from the presence of wildlife. Acceptable mechanisms are evolving on a state-by-state basis. Continuing adaptations can be expected as the results of the ongoing state-by-state experiments emerge.
The definition of success will be adequate compensation for landowners to assure attention to wildlife welfare coupled with hunter acceptance of the mechanism for achieving that end. The aim is a "win-win-win" outcome in which wildlife prospers, landowners have incentive to care for wildlife, and hunters have quarry to pursue and a place to hunt.

\section{Keys To The Puzzle}

The keys to such matters are, as always, money (or some reasonable facsimile thereof), cooperation, open minds, and willingness to follow a new and different path. With money in hand, the officials who show up to deal with the problem have a number of options. They could offer to pay for actual "damages." Or, they could offer a business deal for the rancher to feed some number of deer and elk on an annual basis. Or, they could offer to construct facilities to eliminate or reduce deer and elk damage to, or consumption of, winter feed for livestock. Or, they could provide feed and arrange for volunteers (or employees) to handle feeding chores. Numerous arrangements are possible to fit each unique set of circumstances both fiscal and operational.

But, where does the money, willingness to cooperate, open minds, and flexibility come from? They can arise from frustration with failure. They can arise from the fear of results from interacting decisions made by others far removed from the consequences of those decisions. They can emanate from concern for community, friends and acquaintances, self and family, and - for some the land itself. They can derive from conviction that the increasingly narrow path being followed is not producing desirable nor equitable outcomes. And, finally, they can spring forth from rage at, and fear of, a "system" that is increasing viewed as impersonal, distant, unreason- 
ably controlling, inflexible, and insensitive to local customs and mores.

One of the best sources of money is, and has always been, those who profit most from a particular course of action. In our discussion of the problems and opportunities associated with deer and elk welfare and ranch survival along the interface, the primary group that profits is hunters.

The argument is that those who benefit from management activities should pay, at least, a portion of those costs. It has been convincingly argued that such fees would help insure both hunter welfare and that of the animals which hunters pursue. Hunters need to understand the threat that loss of economically viable ranches along the interface imposes on what used to be a "free lunch," so far as the production of deer and elk from and hunting on national forests is concerned. The proponents were accused of "premature cognition" at the time. But as always, "the times they are a changin".

The issue of making hunters pay for their wildlife on public lands was probed over 15 years ago, and it was suggested that hunters pay a modest fee for hunting on national forests. It was recommended that receipts be divided between national forests for land management, the state wildlife agencies for dealing with deer and elk problems associated with the interface, and counties for roads and schools (as with other sources of revenue such as timber and grazing receipts), and administrative costs.

Based on 1979 data it was estimated that a $\$ 100$ hunting stamp for hunting big game on the national forests would produce about $\$ 57$ million per year for wildlife management in the western states. Dramatic increases in big game hunting since that time make it likely that over $\$ 100$ million could be collected from that source today.

Such fees are easy to justify on the basis that land management activities are being conducted to produce larger populations of big game species primarily for enhanced hunting opportunities. Establishment and maintenance of trails and campsites and patrols to regulate hunter activities and land use add to costs. Many of these costs come in the form of opportunity costs wherein other activities that would produce income are modified or forgone to realize a wildlife management objective such as promoting stable or increased numbers of deer and elk and enhanced hunting opportunity.

\section{The Path Not Taken - Yet}

If the numbers of elk and deer are not judged excessive, many ranchers along the interface do not complain. Some believe that this tolerance is related to the recognition that the quid pro quo for grazing on national forests is acceptance of significant numbers of deer, elk, and other wildlife on their private ranchlands. What if these fees for grazing on national forests were waived, partially or in total, as composition for wintering large numbers of ungulate wildlife?

What if volunteers were recruited and directed in the routine maintenance or reconstruction of fences flattened by elk? What if hunters realized the de facto partnership with ranchers along the interface, minimized the conflicts, and searched for joint solutions? What if the quest was for a win-win solution rather than courses of action that now seem to be producing only lose-lose scenarios? We know, intuitively and from limited experience, that such solutions are possible.

Flexibility remains a stumbling block for those persons of good will who struggle along a new path. Perhaps, it is too much to hope for any immediate revamping of the accumulating mass of overlapping, uncoordinated laws, both federal and state. Although these laws were meant to solve these problems, in many cases they produce nightmares. But, there are precedents for local cooperative groups to acquire dispensation from Congress and the Administration for trying new ways and new approaches. The door has been opened. There is no reason why other groups who have "their stuff together" cannot walk through that open door.

Precedents can be powerful wedges in our political system and beg the question of "you did it for them, why not for us?" Or, even more power resides in the question, "Congressman $X$ and Senators $\mathrm{Y}$ and $\mathrm{Z}$ got the job done for their constituents and we only expect the same results from you. Are you less skilled or less powerful than they?"

\section{National Forests And Grazing \\ Tomorrow}

The Old West lives only in memory and in legend, and to some extent, as a state of mind. The New West is emerging. But what will the New West be, look, and, most importantly, feel like? Who, and by what means, will have any influence over the evolution?

Some factors in that equation are set, at least for the moment, in law, court decisions, manuals, and agency mandates. The "wild card" in the game of molding a New West lies in the human equations. It is in this wild card that hope for the rise of an emerging "radical center" in addressing land-use issues in the New West resides.

This modus operandi is in keeping with the acceptance that "adherence to social norms almost certainly is more important to the functioning of society than maintenance of formal legal structures." The formal contracts related to the administration of grazing permits have taken on attributes of a social contract over the past century. This is, we believe, a situation to be valued, cultivated, and maintained to the benefit of all parties - the FS (i.e., the people of the United States), permittees, and local communities.

This is not to imply that adherence to legal requirements and necessities of good stewardship should be compromised. Many of these working relationships have been strained over the past several decades by increased attention to assured simultaneous compliance of the myriad environmental laws, as interpreted by the courts. This has resulted in efforts to enhance collaborative approaches when dealing with grazing issues at the interface of private ranchlands and national forests.

We see evidence of these new collaboration approaches all over the West. Once bitter enemies, some ranchers and conservation groups are forming new alliances of the 'radical middle ground,' all around the West and figuratively chanting a mantra such as "Cows vs. Condos". 
Conservationists who once opposed grazing on the federal lands realize that they are much better off working with the ranchers for better land management practices than they are living with the alternative of subdivision. Instead of conservationists crying to end ranching subsidies, some groups are actively pursuing alliances with ranchers to insure preservation of wildlife habitat and open space.

The objective of these efforts is to find a platform upon which compromises can be reached that recognize the legitimate values ensuing from a long established "way of life", the associated economic well being of those involved, and the evolution of a land ethic. The evolving process, which has taken several forms, is at its core, both simple and ancient wisdom-"Come, let us reason together".

For example, a group of ranchers and environmentalists in New Mexico have formed the Quivira Coalition, which is dedicated to a "New Ranch" that focuses on managing the land as an ecosystem, experimenting with new methods of herding, timing, rotation, fencing, stream protection, and less destructive land practices, while at the same time enabling the ranchers to make a living. Through demonstration projects, workshops, newsletters, and articles, the Quivira Coalition is working together to provide "common-sense solutions to the rangeland conflict". The unifying force of the coalition is their love of the land and desire to insure their high quality of life for future generations.

We applaud such approaches and believe that they bear much promise to moderate the forces of conflict and acrimony. Such forces in conflict are useful in defining problems, but almost useless in the resolution of the problems identified.

It is reasonable to assume that the viability of livestock operations that include public land grazing would decline to some unknown degree with the loss of federal land grazing privileges, with increases in grazing fees, or additional significant restrictions upon grazing privileges. If any one or more of these factors were to become reality, in combination with any variety of uncon- trolled factors (i.e., drought, depressed markets for livestock and other agricultural products), the result would be a decrease in economic viability and increased probability of sale ranches along the interface to the highest bidder.

With every ranch sale there is the chance for a land conversion to what economists refer to as a "higher and better use," related to more economically rewarding alternatives such as subdivisions. Lands adjacent to national forests, which to many assume will remain in open space, are frequently considered to be prime property for development into home lots or small tracts. When such a land use conversion occurs, it is likely that some of the attractiveness of the national forest, its migrating wildlife, will be negatively influenced by the land conversion.

\section{"Subsidies" Can Be A Good Thing}

So, to the extent that any "subsidy" is involved in public land grazing, it should be considered that the present arrangement is important to some unknown and variable degree, in maintaining the viability of ranching or farming relative to alternative land use, whether for subdivision into home sites or commercial development. To the extent that this is true, it seems logical to assume that the continued retention of this "subsidy" is of value because of its role in the maintenance of open space and associated wildlife habitat. The cost in dollar terms is quite low and the benefit, in terms of maintaining viable ranches along the interface, can only be guessed, and will vary from ranch to ranch. We believe it, overall, to be significant.

Of much greater social/ecological significance than grazing fees, which are miniscule in relation to the overall budget of the FS and the federal budget, is the question of range condition. Under no circumstances should poor or deteriorating range condition, particularly on national forests, be considered acceptable over the long term. Perhaps, we should consider reductions in grazing fees as a reward for achievement of significant and continued progress toward a desired future ecological condition and a "carrot" used in conjunction with the "stick" of compliances with law and regulation..

Such incentives would likely have a three-fold positive effect in that decreased fees (i.e. increased income to the rancher) would improve the economic viability of associated ranches, serve as an incentive for efforts to achieve desired ecological conditions, and soften the effects of any necessary adjustments in grazing programs or range improvements. Range conditions, on average, have slowly and steadily improved on national forests over the past 100 years and continue to do so. We believe that ranges on national forests are in overall better range condition than any time in the past 100 years. Yet, there are still exceptions, particularly in sensitive riparian areas, that should not be tolerated. Significant efforts are underway to address the conditions of riparian zones - even across the boundaries between private ranchlands and national forests.

We believe that more and faster progress will be made toward improvements in range condition on national forests, as well as the maintenance of open space on adjacent private ranchlands (connected with permits on national forests), through the use of incentives and working with permittees on a local basis than will occur from bureaucratic edict and impartation of penalties. That was clear to Secretary of Interior Hitchcock in 1901, and Secretary of Agriculture Wilson and FS Chief Pinchot in 1905. It is equally clear today, in spite of recent trends in centralizing authority of national forest management. One "size" does not, and most certainly in this case, fit all.

This is equally true of exerting influence with grazing permittees of all stripes (corporate or individual), with holdings large and small, and varying degrees of wealth and political "clout". Those who bemoan "subsidies" to "corporate" landholders would do well to understand that incentives influence actions are of the moment and ownerships change over time. Today's private ranch can become part of a national forest or a corporate holding tomorrow. Today's corporate land holdings can be in ownership of a private individual, or the 
government, tomorrow. The operative question is whether or not the land remains in open space.

\section{Open Space is Open Space}

If the paramount concern is maintenance of functioning ecosystems with minimal negative boundary effects, is the financial status of the landholder or the nature of the ownership truly relevant? Open space is open space regardless of ownership, and those with an abiding interest in wildlife (a barometer of ecological health and function) will want all the open space that can be saved as population and economic pressures inexorably increase influence upon land use. Wildlife habitat, aesthetics, watershed values, ecological function and process, and recreational opportunities exist independent of who temporarily owns the land.

What happens on and to that land is the critical factor! Promulgation of class envy in this debate may be an interesting social and political exercise but has little bearing on ecological concerns. The focus should, therefore, be on the land itself, the health of that land, how it is embedded and functions in the landscape, and what it provides now and in the future.
Those of us with an interest in the maintenance of wildlife habitat (i.e. ecosystem process and function) need to very careful in dealing with such issues socially, economically, politically, and ecologically. Making decisions on the basis of shallow slogans and misleading selected data put forward in isolation and for political purposes can have unintended and essentially irreversible serious consequences for maintenance of open space and wildlife habitat along national forest/ private ranchland boundaries.

We believe a more productive course is to repeat and adhere to the ancient admonition - "Come, let us rearm together." These are complex issues, too complex to be addressed without full consideration of historical, economic, legal, and ecological considerations.

After all is said and done, the species Homo sapiens, as all other species, has no choice, but to exploit the environment in order to live and thrive. The operative question, then, is not "whether", but "how." As the "New West" emerges from the detritus of the old, it seems a critical part of the social contract that promises be kept even as essential modifications are made. There is a saying commonly used in India that is applicable to the issues facing the West, "When bull elephants fight, only the grass suffers".
The "conflict industry" that has come into being as the tussles over natural resource management in the West have intensified over the past three decades will not disappear. But we believe that this industry, these fighting elephants, that feed on conflict and distrust will wane in influence as it is increasingly realized that this approach is resulting in deadlock, impasse, and acrimony. None of these outcomes seems likely over the long term, to be acceptable to citizens of the areas most affected.

Of much greater interest, and promise, is the growing numbers of Westerners both new and old - who have concluded that the status quo of being mired in controversy and under the feet of elephants is unacceptable and who, now, seek a better way. For want of a better word, they are collectively reaching out to their neighbors and grasping hands to form a new evolving social entity which many of them refer to, only half in jest as the "radical center." It seems increasingly likely that this movement will reject deadlock, impasse, and acrimony to meet first and most successfully along the interface between private ranchlands and national forests.

Jack Ward Thomas and Stephanie Lynn Gripne are involved with the Boone and Crockett Wildlife Conservation Program through the University of Montana at Missoula. 


\section{Aiming For Range Management Literacy}

\section{A proposed model for developing youth that have not only an awareness, but the abili- ty to act, on range and wildlife management issues.}

By Christine Moseley, Mark Moseley, and Seburn Pense

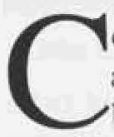

onservation of natural resources and the environment has always been a major focus of youth range camps. It's often assumed that the high school students involved in range camps were "literate" upon completion of the camp; in other words, they had learned and could read and write, and repeat, some information about range management.

However, how does one define literacy and what constitutes a "literate student?" Is being able to read and write about a subject enough to be competent in that subject?

The purpose of this article is to stimulate discussion on what constitutes literacy, or more specifically, environmental literacy and how its definition might apply to the field of range management. We propose a literacy continuum model based on an established environmental literacy model for those professionals in the fields of range and wildlife management who are involved in the development of range camp curricula.

This model will assist range professionals in creating educational teaching strategies so that "graduates" of youth range camps will be literate in range and wildlife management.

Environmental literacy might best be understood by reviewing other models and definitions of literacy in various discipline areas. More understanding may be achieved by specifically reviewing the historical definition of literacy and its impact on the development of reading and agricultural literacy.

\section{Literacy Defined Historically}

Historically, the overall goal of education has been to create a society of literate citizens. The first law on public education (The Code of 1650) called for reading literacy so that an informed citi-

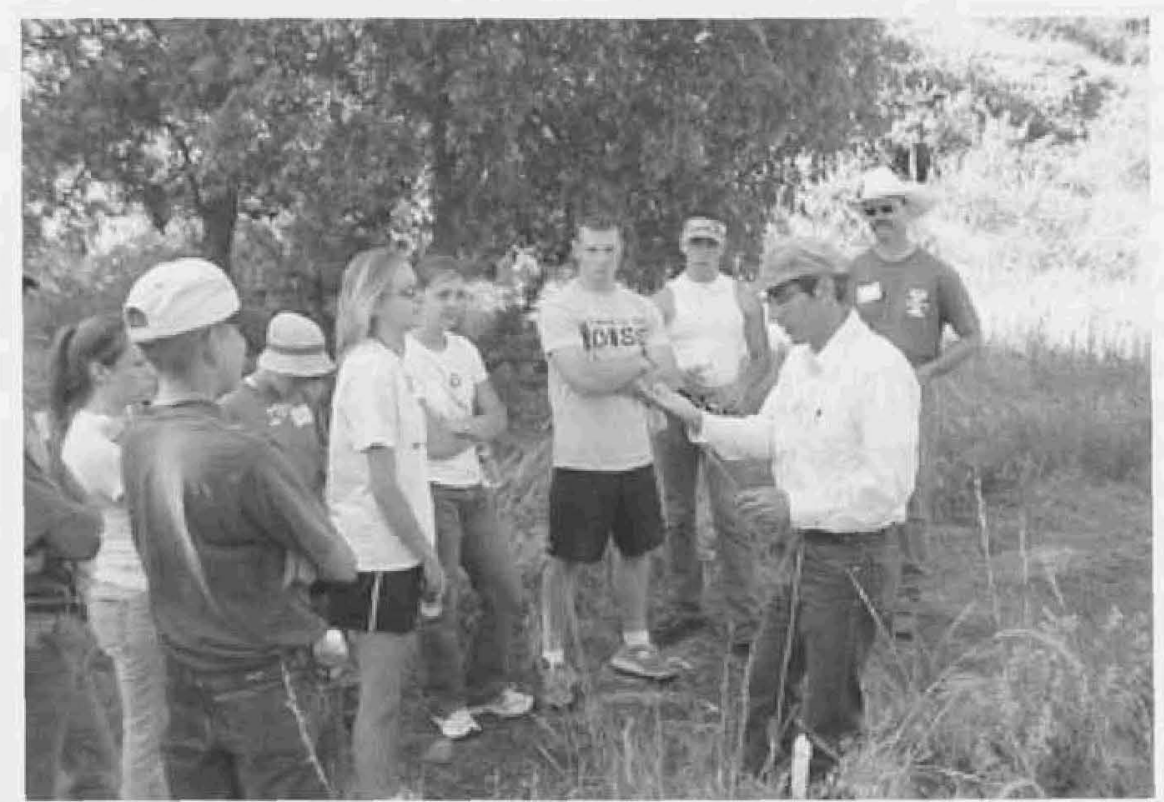

Students participating in plant identification with Ben Berlinger.

zenry would be able to read the Bible and learn morality. This would ultimately result in the electorate passing legislation that would preserve an upright society.

Dictionaries now generally define literacy as the ability to read and write; and, to be well educated, having or showing extensive knowledge, learning or culture. The challenge now for anyone involved in the education of a literate citizenry is to define and clarify what it means to be "well educated", that is, to have literacy and establish this as standards for the educational community.

From this premise several models for literacy have been developed, especially in the areas of reading, agriculture, and environmental education.

\section{Reading Literacy Model}

It is generally agreed that in reading literacy a number of stages are involved
- from recognizing the alphabet to building the letters into words and phrases to decoding the written words for meaning.

It is commonly recognized that there are degrees of literacy ranging from those who can minimally decode such things as the words on signs to those who can read and understand newspaper accounts to those who easily read and comprehend great literature or complex scientific journals. The functionally literate reader is able to recognize the alphabet and can decode basic signs and key phrases or simple words, whereas an academically literate person shows extensive skill in reading, decoding, and comprehending a variety of complex writings.

Do other forms of literacy, such as environmental or agricultural literacy, encompass a similar developmental continuum? If so, are there reasonably rec- 
ognizable degrees of literacy? If that is the case, when a program states that it develops literacy, can we ask: To what degree and at what level?

It would seem only fair that only when these questions can be answered is it possible to assess the potential of a proposal or the degree of success of a functioning educational program.

As adult sponsors and curriculum developers of traditional summer range camp programs for high school youth, we agree that the ultimate goal of the range camp curriculum, as with any educational program, is to produce a literate youth population. However, we are now beginning to ask the same questions as above: To what degree and at what level does the range camp program develop literacy? How can we recognize that the participants have acquired literacy? Most importantly, is there such a thing as "range management literacy" and if so, how should it be defined and recognized?

\section{Environmental Literacy Model}

In 1990, the United Nations Educational, Scientific, and Cultural Organization (UNESCO) defined environmental literacy "as a basic functional education for all people, which provides them with the elementary knowledge, skills, and motives to cope with environmental needs and contribute to sustainable development."

Since 1990 educators in the field of environmental education have attempted to clarify and refine this broad definition in order that it may be used in goal and objective planning and in assessment of programs developed to promote environmental literacy.

Environmental educators now generally recognize that there are stages of accomplishment in developing environmental literacy, best determined by observed behavior. Three major cluster areas of a proficiency continuum exists that individuals progress along in degrees towards acquisition of environmental literacy:

- Nominal Environmental Literacy is the ability to recognize many of the basic terms used in communicating about the environment, and to provide a rough working definition of their mean- ings. Developmentally, the nominally environmentally literate person, although aware of the terms or vocabulary, has little or no depth of understanding of them, has only rudimentary process skills, and no more than casual commitment to environmental concern and action.

- Functional Environmental Literacy is the capacity to use fundamental environmental knowledge, concepts, and thinking skills to formulate action positions on particular environmental issues and in daily behavior. The functionally literate person can communicate the substance of an account to a third party, either orally or in writing.

- Operational Environmental Literacy is the capacity to regularly perceive environmental issues, gather and evaluate pertinent information, examine and choose among alternatives, take actions that work to sustain, and develop the foundation of environmental knowledge along with the elements of questioning, analytical and deductive reasoning, logical thought process, and reliance upon objective analysis.

People tend to progress along the continuum of proficiency in environmental literacy in stages that include awareness and concern, knowledge and understanding, and behaviors and action. Capability at the nominal or functional developmental stage of literacy is not achievement of the ultimate operational literacy. A person who is environmentally aware is not yet environmentally literate; neither is a person who possesses broad environmental understanding or who demonstrates environmental concern.

Moreover, one who only takes action on an environmental issue is not considered literate. One demonstrates operational environmental literacy only when all the components come together in the actions taken.

Research into environmental behavior does not bear out the validity of a linear model for changing behavior. Knowledge and awareness of the environment and environmental problems are certainly prerequisites to appropriate action. However, some research reveals that knowledge and awareness of action skills are also prerequisites for taking

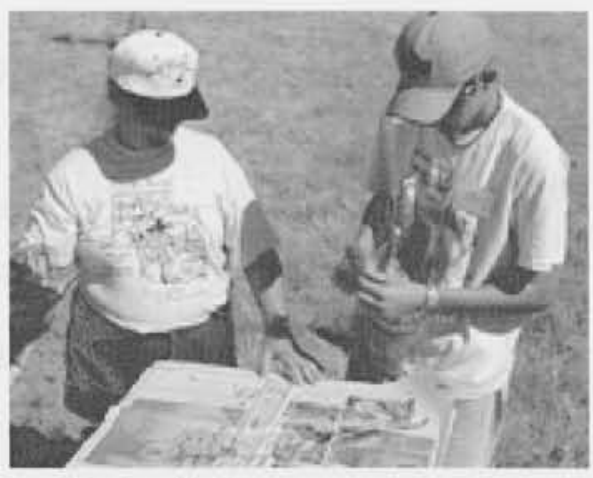

Plant collecting.

action. Furthermore, students need to be specifically trained in problem-solving skills, and this training needs to be incorporated into the instructional practice of environmental education.

Responsible environmental behavior is a learned response or action. As the ultimate goal of environmental education, it is synonymous with environmental literacy. Consequently, the ultimate goal of environmental literacy is acquiring life-sustaining, responsible, environmental action skills. It is recognized that knowledge and sensitivity to a problem is a prerequisite to appropriate action.

However, knowledge of the problem is only part of the catalyst required. A student must also know what he/she can do to help and how to take action. Teaching students only environmental awareness and knowledge are not enough. Instruction and modeling of action skills must be done in and out of the classroom.

\section{Agricultural Literacy Model}

Agricultural literacy is no less important than reading literacy or environmental literacy to the well being of a nation. Indeed, Sir Horace Plunkett once said, "The well-being of a people is like a tree: agriculture is its root, manufactures and commerce are its branches and its life; if the root is injured, the leaves fall, the branches break away, and the tree dies." (Shepardson 1929, p. 3).

It is not difficult; then, to understand that agriculture must be protected if a nation is to thrive legally, politically, and culturally. To preserve and protect agriculture in the United States, citizens must be agriculturally literate if they are to enact laws that will not only protect but also promote this industry. 


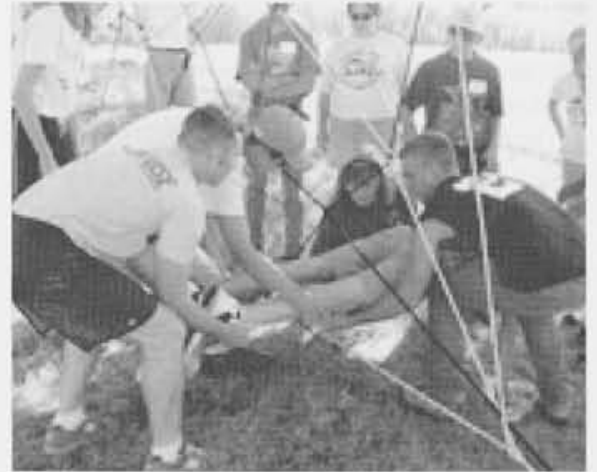

The Challenge Course.

In 1988, the National Research Council's Committee on Agricultural Education in Secondary Schools proposed that an agriculturally literate person would understand the Food and Fiber Systems in relation to its history, economic, social, and environmental significance. Traditionally, agriculture has been defined as the science, art and business of cultivating the soil, producing crops and raising livestock. A more comprehensive definition of Food and Fiber Systems also includes the management of wildlife, range lands, forests, rivers, oceans and natural resources.

Frick, in 1990, reported one of the first conclusive agricultural literacy definitions: "Agricultural literacy can be defined as possessing knowledge and understanding of our food and fiber system...An individual possessing such knowledge would be able to synthesize, analyze, and communicate basic information about agriculture" (p. 52).

\section{Does Range Management Literacy Exist?}

As we searched the literature for comprehensive definitions of literacy, a pattern began to emerge, regardless if the definitions were for reading, environmental or agricultural literacy. Each of the definitions include the concept of learning proficiency and competency based upon a continuum, and that individuals progress along the continuum from awareness, to acquisition of knowledge and development of skills, and further application of those skills and content to undertake appropriate action.

To be truly literate in any discipline requires competency in all aspects along the continuum. A study done by Gambro and Switzky (1996) of a national sample of American high school students confirms that assertion. A majority of the students in that survey were able to recognize basic facts concerning natural resources and environmental problems; however, most students could not apply their knowledge to comprehend the consequences or potential solutions related to the problems and issues. Thus, they would not be considered fully literate in the areas of natural resources and environmental education.

As educators involved in agriculture, we believe that the definition of agricultural literacy should be expanded beyond "knowledge and understanding" to include appropriate skills, actions and behaviors, as defined in environmental literacy. Students must not only be taught facts and information about their natural resources, but also be taught how to take appropriate action and responsible behavior for sustainability of those resources.

Thus, as educators involved in developing curriculum for a range camp, we are now challenged to go beyond the traditional emphasis of content. Content and knowledge alone are not enough, as research suggests. We must also teach the skills that these future students must have to become an operationally agricultural literate citizen.

How does this happen? What actions and responsible behavior do we want the youth of today and voting citizens of tomorrow to take? As range camp curriculum developers, we first must decide what are the overall goals and objectives of our program. Too often, educational programs are developed around a set of facts and content that must be taught, with little consideration given to the purpose of the program itself and what it ultimately wants to accomplish.

Second, those individuals involved in the development of the curriculum must become familiar with a literacy model, whether environmental or agricultural, and choose an appropriate one consistent with the program's goals and objectives.

Third, the range camp curriculum must be designed to achieve complete literacy, with appropriate behavior skills identified, based on the "new" definition of literacy as interpreted by the curriculum developers. All too common in educational programs, appropriate and effective assessment is lacking.

Reflective follow-up assessment to measure success of the program regarding achievement of the goals and objectives must be done and this assessment then used to revise and improve the curriculum.

\section{Future Implications: Range Management Literacy Continuum Model}

We have been involved in the development of youth range camp curricula for the past ten years. As our previous training in the field of range management directed, we initially emphasized facts and figures and demonstrated technical applications of that information. We assumed that was enough; that the students were "getting it." We never sought to define "it!"

With the current research in the area of environmental literacy as a curriculum outline, the fundamental techniques of curriculum development as a model, and the principles of range and wildlife management as a knowledge base, we are now revising our curricula and seeking to produce a competent, literate student in the field of range management.

We have had to ask ourselves the hard question, "Are graduates of our range camp literate in the field of range management?" Until we began to fully understand and implement the working definition of literacy... acquisition of knowledge and skills and application for appropriate behavior...we had to sadly admit that our graduates were not truly literate.

Our weeklong curriculum is now developed around activities and teaching strategies that give students opportunities to progress along the literacy continuum from awareness, to acquisition of knowledge and skills, and application of those skills and content for appropriate action. Each of the day's activities build upon this continuum with the ultimate objective of having students participate 
Table 1. Literacy Continuum Model for Youth Range Camp Curriculum

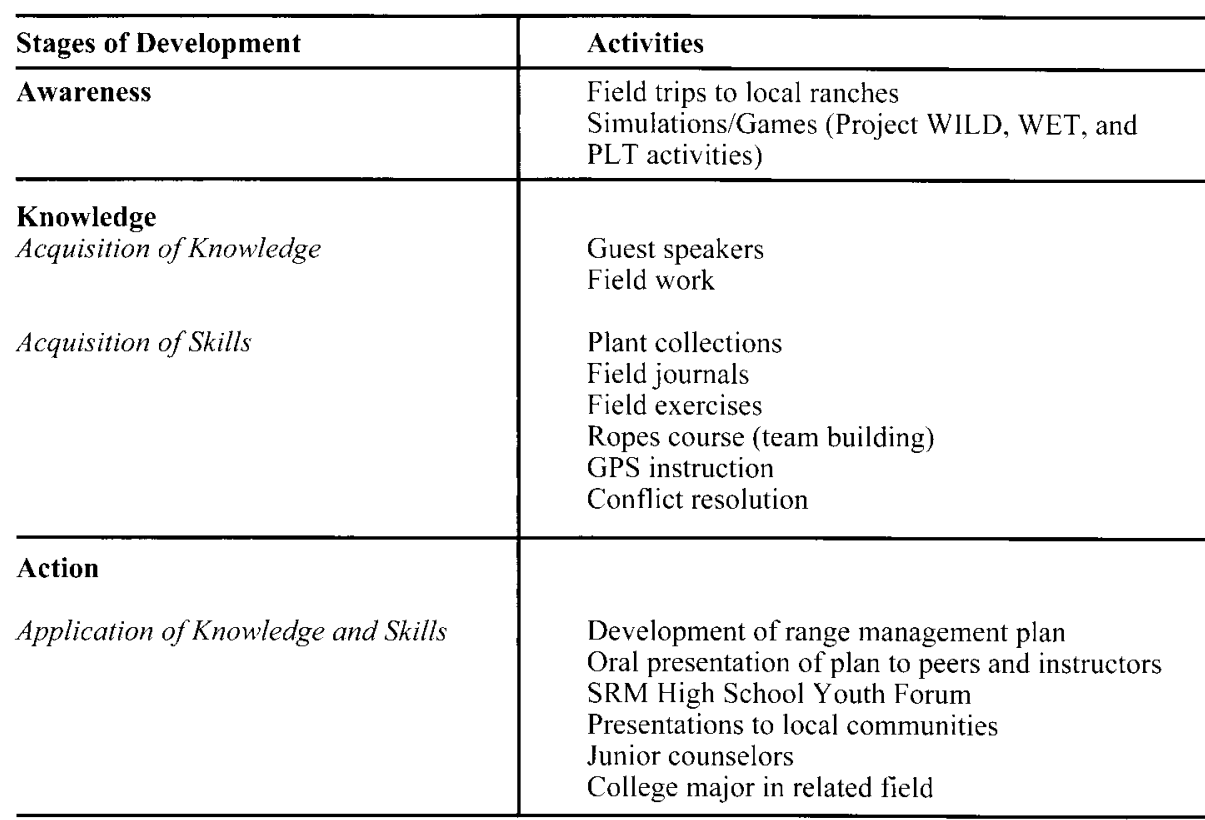

in a culminating problem solving project, where they are required to use the skills and knowledge that they have acquired throughout the week.

This final range management plan, done together in cooperative groups, requires the students to develop land management objectives, conduct a site inventory, prescribe practices that meet their objectives, and defend their plan orally to peers and instructors. Table 1 outlines activities that students are involved in throughout the week addressing the four stages of literacy development.

With this literacy continuum in mind, our major goal as range camp instructors are to "graduate" students who not only are aware of range management issues and have some knowledge and skills of range management principles, but who are able to apply that knowledge in problem solving situations.

The Cognition and Technology Group (1990) defines inert knowledge as "knowledge that can usually be recalled when people are explicitly asked to do so but is not used spontaneously in problem solving even though it is relevant" (p. 2). Teachers must make information meaningful to students and train students to use their knowledge as an instrument for problem solving. When students learn new information in meaning- ful contexts (under problem-solving conditions), they begin to understand the various circumstances in which to apply concepts and facts.

Hopefully, the problem of inert knowledge can be at least partially avoided through the use of specific instructional techniques that provide a purposeful, problem-oriented context for learning rather than techniques that employ a fact-oriented approach. The interdisciplinary nature of range management issues provides an ideal opportunity for meaningful, integrated, and problem-oriented instruction. In addition, this proposed literacy model provides an outline for the development of effective curriculum and instructional strategies that take advantage of the integrated nature of range management.

Dr. Christine Moseley is an Assistant Professor of Science Education at Oklahoma State University in Stillwater. Mark Moseley is State Range Conservationist at the Natural Resource Conservation Service, Stillwater, Okla.; and Seburn Pense is a Ph.D. Candidate, Agricultural Education, Oklahoma State University, Stillwater, Okla.

\section{References}

Cremin, L. 1988. American Education: The Metropolitan Experience. New York: Harper and Row.

Disinger, R. and C. Schoenfield. 1978. Environmental education today. Environ. Tech., 1:25-31.

Frick, M.J. 1990. A definition and the concepts of agricultural literacy: A national study. Unpublished doctoral dissertation, Iowa State University, Ames, Iowa.

Gambro, J. and H. Switzky. 1996. A national survey of high school students' environmental knowledge. J. of Environ. Edu., 27 (3):28-33.

Hirsch, E.D. 1988. Cultural literacy: What every American needs to know. Boston: Houghton Mifflin.

Hungerford, H.R. and T.L. Volk. 1990. Changing learner behavior through environmental education. J. of Environ. Edu., 21(3): 8-20.

Leising, J.G. and Zilbert, E.E. 1994. Validation of the California agriculture literacy framework. Proceedings of the National Agricultural Education Research Meeting, USA, 21: 112-119.

National Research Council, Board on Agriculture, Committee on Agricultural Education in Secondary Schools. 1988. Understanding agriculture: New directions for agricultural education. Washington, D.C.: National Academy Press.

Osler, A. 1999. Citizenship, democracy and political literacy. MCT, 18(1), 12-15, 29.

Ramsey, J. 1981. The effects of environmental action and environmental case study instruction on the overt environmental behavior of eighth-grade students. J. of Environ. Edu., 13(1): 24-30.

Roth C.E. 1991. Towards shaping environmental literacy for a sustainable future. ASTM Standardization News, April: 4245.

Shephardson, W.H. 1929. Agricultural education in the United States. New York: Macmillan Company.

The code of 1650 , being a compilation of the earliest laws and orders of the general court of Connecticut. 1822. Hartford: Silus Andrus.

The Tbilisi Declaration. 1978. Connect 3, $1: 1-8$.

The Cognition and Technology group. 1990. Anchored instruction and its relationship to situated cognition. Educational Researcher, 19: 2-10. 


\title{
Listening To The Land
}

\section{Speaking From The Heart}

\author{
By Thad Box
}

The decade of the 1930s was one of unprecedented social and economic hardship. Wall Street signaled the beginning of the Great Depression with the stock market crash in 1929. As the depression developed, millions of people went hungry. There were no jobs, no money, no hope, especially for those who lived in cities.

Those who lived close to the land, farmers and ranchers, became totally dependant on the land and climate. Poor markets for their produce meant they had no money. But if the weather cooperated, they did not go hungry. Simple meals consisted of what they raised. Most agricultural lifestyles were similar to subsistence farmers in third world countries today.

Tenant farmers were less fortunate. The poverty normally associated with share cropping turned to squalor and starvation as families were put off farms by landowners seeking economic gain from mechanization and government programs. The characters in Steinbeck's "Grapes of Wrath" became the classic new class of landless folks roaming the country looking for work.

Marginal farmland had been plowed and planted to increase production for the "War to end all Wars." Rangelands were stocked to the fullest during World War I. Uncertain markets following the war led to continued overstocking during the 1920s. Poor cattle nibbled each emerging shoot of green on most ranges. Large landless herds of sheep roamed the public mountain ranges of the West, dust clouds billowing behind each flock.

Economic conditions were exacerbated by drought over much of the western rangelands. Abused and overused land received scant moisture for natural regrowth. Thunderstorms falling on bare land caused mud slides and erosion. Wind blew dust all the way to Washington.

President Franklin Roosevelt's New Deal began a process of national recovery in the early 1930s. Many make-work projects were directly related to land rehabilitation. The work groups spawned a cadre of landcare workers that became professional land managers in the next generation.

The Civilian Conservation Corps (CCC), Work Products Administration
(WPA), National Youth Administration (NYA) and other groups built terraces, planted trees, developed campgrounds, and seeded rangelands.

Some who joined government programs just to have a job went on to study forestry, ecology, and soil conservation at western universities.

\section{Enter The Era Of Rehabilitation}

Land was abused by people, the economy, and the weather. The condition of the land became a national issue. Federal programs were established to institutionalize the newfound public concern for land.

The Soil Conservation Service was formed to address the problems on private land. The Taylor Grazing Act passed to protect public lands. The Bureau of Land Management was born. The USDA Forest Service became a leader in management of wildlands. Its research was uniquely suited to western landscapes. Curricula emphasizing principles of ecology in land management were available at most western universities. There were increasing jobs available for people trained in care of rangelands.

People working on rangelands were scattered among different agencies and professions. Though most had an ecological approach to management, they were trained in a number of disciplines. They lacked common techniques and inventory procedures. They were bound together only by their dedication to a special kind of land.

A number of interagency committees were formed to address rehabilitation of western rangelands. Participants came from the Forest Service, Soil Conservation Service, Bureau of Indian Affairs, Bureau of Land Management, and various state universities and experiment stations.

Between 1931 and 1936 at least five groups seriously considered forming a professional society for range workers. With the coming of World War II, such discussions were put on hold.

After WWII, Vernon Young hosted interagency range workers at the University of Idaho to consider formation of a separate society for professional range workers. The majority of attendees favored a new organization specifically designed to serve rangeland needs.

Strong minorities spoke for sections in existing societies such as the Society of American Foresters, American Society of Agronomy, American Society of Animal Production, or the Ecological Society of America. A committee headed by Joe Pechanec and Harold Heady was charged with determining the kind of organization range workers wanted.

Known range management workers were queried by letter, working committees appointed to draft constitution and bylaws, temporary officers selected, and a date for an organizational meeting selected. In January 1948 the American Society of Range Management was formed at the old Newhouse Hotel in Salt Lake City, Utah. Joe Pechanec was elected President. W.T. White became Vice President and Harold Heady Secretary.

The first Council consisted of Bill Allred, David Costello, Fred Renner, George Stewart, Laurie Stoddart, and Vernon Young. One of their first decisions was to publish a journal where research findings could be disseminated and policy matters debated. American rangelands, for the first time, had a unified voice backed by an official organization of professional people.

From the beginning, the voice was diverse. A major organizational debate was over qualification for membership. One faction wanted membership restricted to people with documented training in land management. Another wanted membership open to practitioners, especially ranchers. In the end, the organizers decided the society should be open to anyone with an interest in rangelands. The Society would speak from its heart as well as its head

The new society valued land as a medium to support human life and lifestyles. It contained folks who acted from concern and implemented technology. The Society still debates whether members should be scientists or practitioners. The prime requirements remain the ability to listen to the land and care about people. Members speak from the heart while they apply science to land. 


\section{Sixth In A Series}

\section{The Importance Of China's Nomads}

\section{The sustainable future development of China's rangelands depends on integrating nomads' indigenous knowledge.}

\section{By Daniel Miller}

The author is a rangeland ecologist, based in Washington, DC, and consults on pastoral development projects in China and Mongolia. His email is: wildyakman@hotmail.com

Editor's Note: The International Affairs Committee sponsored a symposium entitled "Rangeland Professionals and Society: Future Directions' at the 2001 annual SRM meeting in Kona, Hawaii. From those presentations, a series of articles has been published in Rangelands highlighting perspectives on rangelands from around the world. The following four articles profiling rangelands in China, Africa, Australia and Canada are the last in the series. The editors and authors wish to thank Dow AgroSciences of Indianapolis, Indiana, for a grant made in support of the symposium.

Rangelands cover $40 \%$ (400 million ha) of China's land area making China second only to Australia in the extent of its rangeland resources. About $75 \%$ of China's rangelands are found in the semi-arid pastoral areas in the north and west, with the Tibetan pastoral area, comprising 140 million ha, the largest.

China has some 260 pastoral counties, which accommodate about 39 million people, including some of the poorest people in China. Many of them are nomadic pastoralists who are very susceptible to changes in the health and productivity of the rangelands from which they obtain their livelihood.

China's rangelands have been used for livestock grazing for thousands of years. Yaks are believed to have been domesticated on the Tibetan Plateau about 4,500 years ago, and the construction of the Great Wall, which was built to control nomadic societies, was initiated 2,000 years ago. History among nomadic pastoralists in China is the result of multifaceted interactions among cul- ture, ecology, and personal actions. Over centuries, nomads acquired complex indigenous knowledge of their rangeland environment and the domestic animals they herded.

The future of China's rangelands is of increasing concern. The rangelands of China are the headwaters for many of Asia's major rivers, and what takes place in these grazing lands has implications for millions of people downstream. A number of China's rangeland ecosystems are also recognized as global priority areas for conservation of biodiversity, as they contain highly distinctive species, ecological processes, and evolutionary phenomena. Despite their extent and importance, China's rangelands are degrading seriously, and the country's range managers face many challenges.

As a first step, the sustainable future development of China's rangelands must recognize the significance of nomads' indigenous knowledge of the environment and management of rangeland resources.

Indigenous knowledge is the unique, traditional, local knowledge that people have of a particular geographic area. The development of indigenous knowledge systems (which covers many aspects of life, including rangeland management and animal husbandry) has been a matter of survival for nomadic pastoralists throughout China, including those on the Tibetan Plateau.

Indigenous knowledge systems of nomads are cumulative, representing generations of experience herding livestock, careful observations, and trial-and-error experiments. This knowledge enabled nomads on the Tibetan Plateau, for example, to develop sophisticated range- livestock management practices in an environment that posed considerable risks. Indigenous knowledge systems are also dynamic as new information is constantly being added.

\section{Nomads Are Skilled Range Managers}

Nomads raise native livestock that are adapted to local environmental and production constraints. For example, Tibetan nomads raise the yak, which is superbly adapted to the high altitude and the cold environment of the Tibetan Plateau. Native Tibetan sheep and cashmere-producing goats are also important species of livestock.

Tibetan nomads usually raise a mix of livestock species each of which has its own specific characteristics and adaptations to the environment. The multispecies grazing system combines yaks, sheep, goats and horses together and

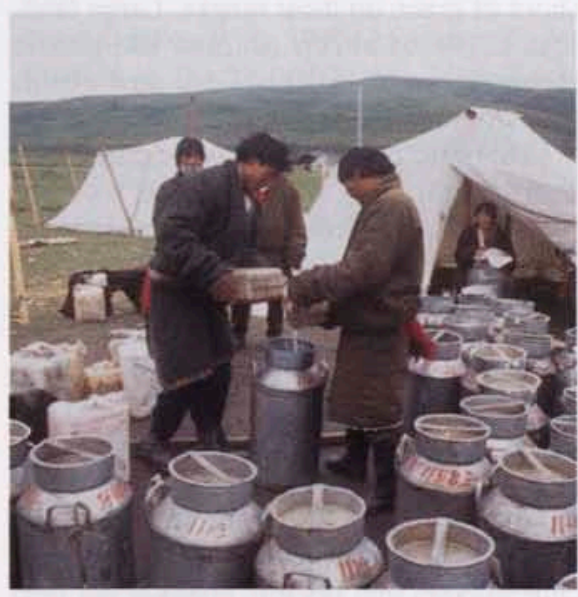

Tibetan nomads selling yak milk. Photo by Daniel J. Miller 


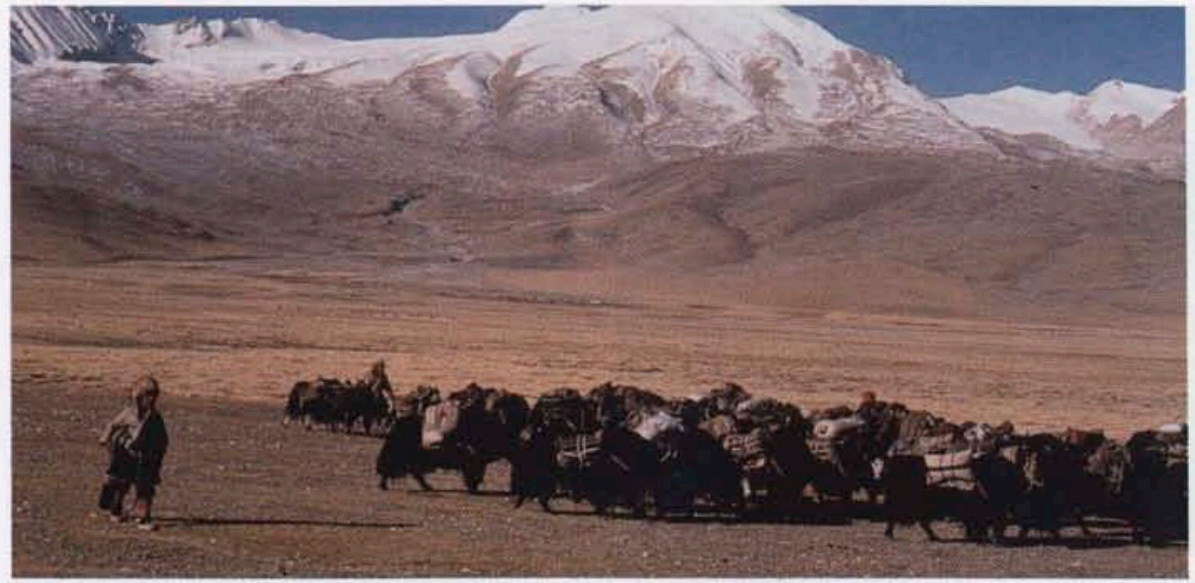

Yak caravan at 4,800m, Tibet, China. Photo by Daniel J. Miller

maximizes the use of rangeland vegetation. Different animals also have varied uses and provide diversified products for home consumption or sale. Large numbers of male yaks are often kept as pack animals, and male yaks and sheep/goats are used to provide animals for sale and for nomads own consumption.

Livestock mobility and flexible use of rangeland were strategic elements of traditional Tibetan pastoralism and the keys to survival. Rangelands are parceled into seasonal pastures and used according to diverse managerial and production objectives. The traditional nomadic pastoral systems that evolved used extensive grazing management strategies adapted to local environmental conditions. Tibetan nomads, like nomads elsewhere in China, did not move randomly across the rangeland; rather their movements were often well prescribed by complex social organizations and were highly regulated.

Environmental risks on the rangelands were mitigated through livestock and grazing management strategies. Livestock mobility, flexible use of rangelands, and diverse herds were key elements of traditional pastoral production systems and contributed to the high ecological stability of the pastoral systems. Nomads maintained a diverse mix of goals for livestock production and survival; they kept a diverse mix of livestock in terms of species and class; and they used a diverse mosaic of rangeland sites, exploiting seasonal and annual variability in rangeland resources.

The flexibility of traditional Tibetan

nomadic pastoralism (which emphasized multi-species herds, complex herd structures, regular movement of livestock, and linkages with agricultural communities) developed as a rational response to the unpredictability of the ecosystem. The survival of numerous prosperous groups of Tibetan nomads bears witness to their extraordinary indigenous knowledge, resourcefulness, and animal husbandry skills.

Tibetan nomadic pastoralism evolved through long-term adaptation and persistence in a harsh environment and the grazing and livestock management systems that developed were intelligent, aggregate behavioral responses by Tibetan nomads to the resources and risks of one of the most inhospitable rangeland environments on earth. Because they are skilled, experienced, proficient, expert, able, adept, and masterful, Tibetan no-

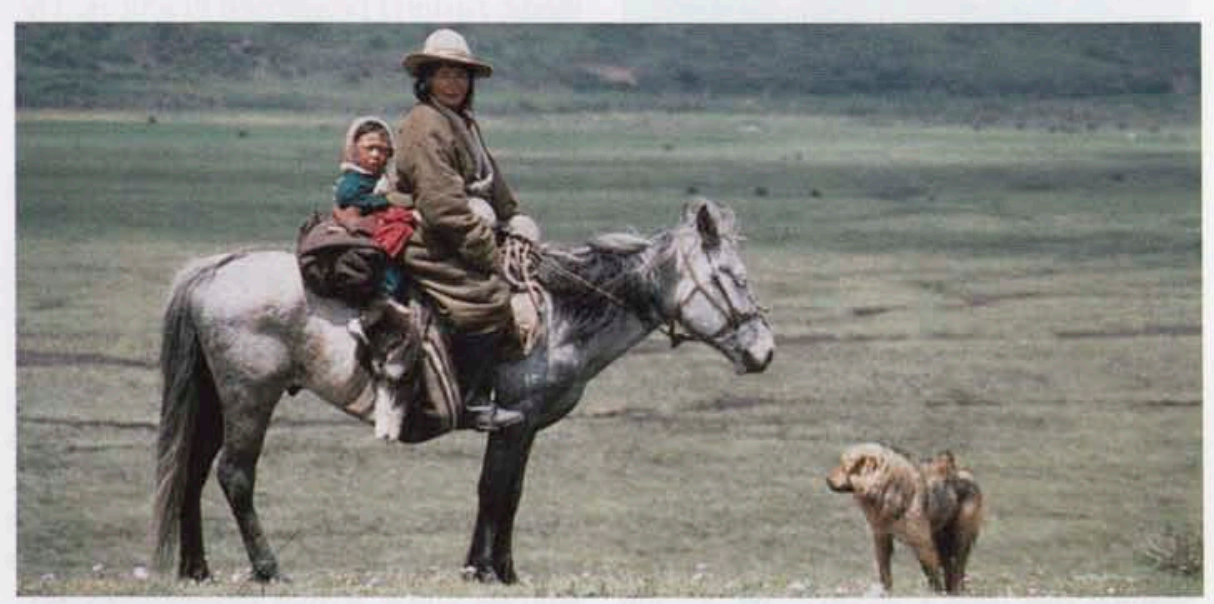

Tibetan pastoral woman at Sichuan Prov., China. Photo by Daniel J. Miller

mads, like nomads throughout China, are "professional" range managers, despite being illiterate.

\section{China's Rangelands Are Being Cropped}

Traditional livestock production and grazing management strategies throughout much of the pastoral areas of China have been greatly altered in the recent decades as the nomadic pastoral way of life has been transformed to one more oriented toward a market economy.

The goal of livestock production in most pastoral areas is now to increase livestock off-take, which has been promoted through privatization of herds and rangeland, less migration by the nomads, intensive grazing management strategies, and introduction of rain-fed farming techniques for growing forage and fodder. Large areas of rangeland have also been converted to cropland, which is one of the primary causes of rangeland degradation.

Many of these interventions have been responses to political or economic objectives but, in many instances, they have conflicted with the goal of maintaining rangeland ecosystem health and stability. The promotion of improved and scientific animal husbandry systems has also jeopardized many worthy aspects of traditional nomadic pastoral systems. Both the rangeland environment and the indigenous nomadic pastoral cultures are under threat in areas where the culture of mobile pastoralism has been eliminated or substantially reduced. 


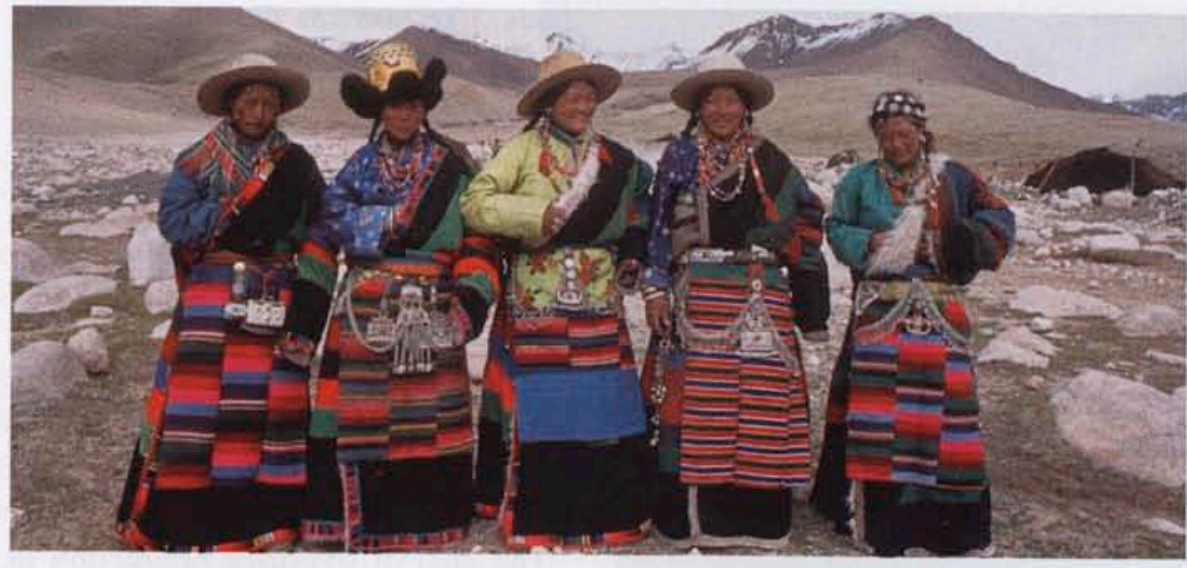

Tibetan nomad women, Tibet, China 5,000 m. Photo by Daniel J. Miller

Large tracts of China's rangelands are now degraded. It's estimated that about $34 \%$ of all rangelands in China are moderately to severely degraded and about $90 \%$ are degraded to some degree. Inner Mongolia, Xinjiang and Gansu are experiencing degradation levels well above the national average.

Current livestock production systems in many of the pastoral areas of China now appear to be unsustainable and the development of intensive livestock production systems as a means to increase production of livestock products and alleviate poverty in pastoral areas will place additional pressure on rangeland ecosystems.

In China, many attitudes towards rangeland ecosystems appear to be influenced by the notion that sedentary

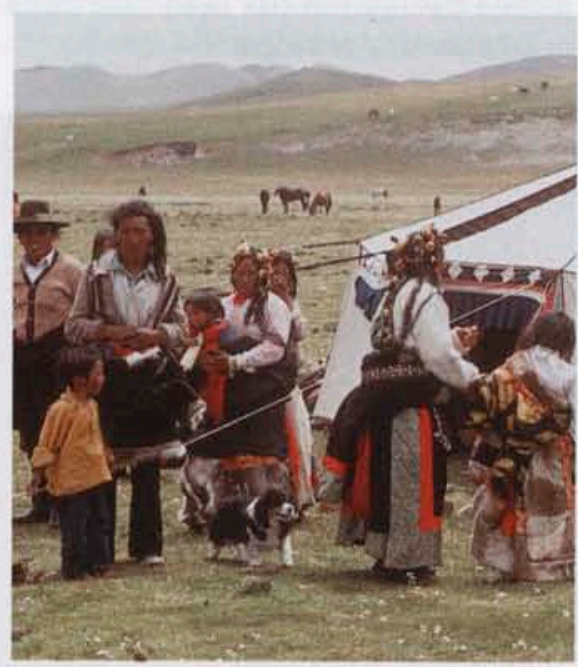

Tibetan nomad family. Photo by Daniel J. Miller agriculture, particularly crop-based agriculture, is the superior development option. Rangelands are viewed as systems to be controlled and modified, much like cropland, rather than to be managed as natural ecosystems. This view is reflected in many of the terms like grassland construction and grassland ecological-engineering that are used in discussion of pastoral development. Development is focused on agronomic and production aspects instead of ecological sustainability. There appears to be little acceptance of the fact that most of the rangelands in China are of low productivity or that this situation is unalterable, either for ecological, technical and/or economic reasons.

\section{New Thinking And Research Needed}

There is a similarly narrow-minded view of the validity of traditional nomadic pastoral production practices. The purposeful movement of nomads' herds is often viewed as wandering and an unsound type of use of the rangeland, instead of an efficient utilization of forage. Nomads themselves are often perceived as backward and ignorant. search findings which suggest that nomads possess considerable indigenous knowledge and that many of the traditional nomadic pastoral strategies and practices are rational and ecologically and economically sound, given the environmental and socio-economic constraints under which nomads operate. These findings suggest that fresh, objective assessments of nomads and no-
These views are not supported by re- madic pastoral systems in China need to be made before completely discarding them.

The issue is compounded by the limited approach taken to rangeland ecosystem research in China. Researches have generally neglected such topics as the effects of traditional pastoral systems on rangeland ecology, the dynamics of herd growth and traditional risk management strategies among nomads, and the impact of large numbers of farmers into pastoral areas to convert rangeland to cropland.

Other problems include a general lack of applied, interdisciplinary ecosystemlevel research, which would provide a better basis for developing more integrated and sustainable rangeland and pastoral development programs. A disproportionate amount of rangeland research is directed towards livestock production rather than understanding how livestock fit into the wider ecological system and how to optimize production in an environmentally and socially sustainable way.

Nomads have played an important role in the rangelands of China for thousands of years. As such, the social dimension of rangeland ecosystems should be an important aspect of research and development in the pastoral areas but, unfortunately, it is not. Thus, little information is available about nomadic pastoralism and misconceptions abound with regards to nomads and their way of life. In China, both organizational divisions between academic disciplines and the intellectual assumption that views human beings as separate from their natural environment have impeded the integration of social and natural scientific research in rangeland environments.

The rationality of nomadic practices needs to be better acknowledged and nomads' indigenous knowledge has to be incorporated into research and development programs. Paying attention to nomads' indigenous knowledge can create more respect for traditional pastoral systems and foster partnerships for resolving issues. Better acknowledgement of nomads' knowledge systems can help build a more sustainable future for the rangelands of China. 


\title{
Seventh In A Series
}

\section{The African Scene}

\section{Environmental legislation and developing resource-poor rural African economies will create opportunities for range scientists in this country. But, future range professionals will need to have wholly-integrated skills.}

\author{
By Peter J. K. Zacharias
}

Faculty of Science and Agriculture, School of Applied Environmental Sciences, University of Natal, Private Bag X01 Scottsville, Pietermaritzburg, 3209 SOUTH AFRICA.

Since its start 60 years ago, range science in Africa has been driven from a hub of intellectual capacity centered in southern Africa. This was housed initially (ca. 1940's) at the Universities of Natal (Pietermaritzburg) and the Witwatersand (Johannesburg) and, later enhanced through development of a research and extension capacity in Northern and Southern Rhodesia (now Zambia and Zimbabwe). This endeavor was fostered by provincial and national government agencies.

All aspects of the discipline were strengthened by the development of Pasture Science departments during the 1960 's at the University of the Free State, some Technical Colleges, and in general plant-science groups at the Universities of Fort Hare, Stellenbosch, Pretoria and Potchefstroom.

The range research endeavor has been strongest in southern Africa with the majority of locally trained contributors emerging from Natal and Free State. However, in all countries the research capacity has always been low relative to other fields, such as animal science, agronomy, engineering, etc. South Africa is the only country in Africa to have developed a research institute dedicated to rangeland science but this took over five decades.

This contrasts starkly with the veterinary institutes established at Pretoria and Pietermaritzburg (South Africa) and Asmara (Eritrea) over a century ago. Although animal diseases, such as Rinderpest and East Coast fever, had the potential to destroy the economies of the

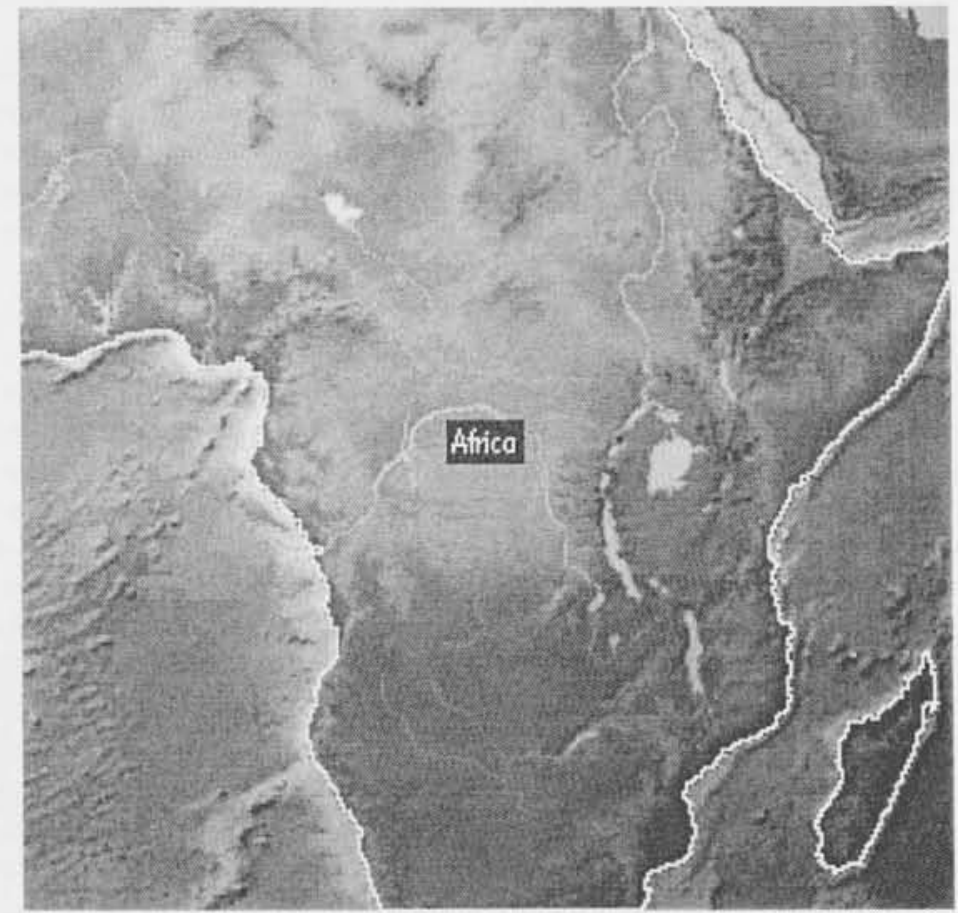

regions at the time, the long-term consequences of ignoring rangeland issues is now evident in many parts of Africa, and in some cases is contributing to the poverty trap.

\section{African Range Science Has A Poor Image}

The discipline was formalized with the founding by the Natal group in 1966 of the Grassland Society of Southern Africa (GSSA) and from this the Grassland Society of Rhodesia, now the Grassland Society of Zimbabwe (GSZ). Today the activities of the GSZ are limited to technology transfer, mainly with the assistance of scientists from South Africa. The GSSA is primarily the custodian of Range Science with annual congresses and peer reviewed publications since 1966. In addition, several technology transfer events since the late 1980 's have been facilitated through farmers' days and special publications. The African Journal of Range and Forage Science, produced and funded by the GSSA, remains the only African publication dedicated to Range Science.

Despite these activities, the discipline is not well recognized - especially among policy makers who still tend to believe that foreign scientists must be better. There appear to be two main rea- 
sons for this: (1) a weak professionalism and 2) poor epistemology - a poor understanding of the basis of knowledge.

I consider critical elements of professionalism to be a strong technical competence and a high level of integrity and ethics. By definition range science is integrative and is actual when applied, but the science also has a large portion of intuition and conventional wisdom in its application. Investigating any "recommended" range practice will reveal that the understanding of this discipline is weak. This may be the reason why we have a poor image.

Societies such as the GSSA, GSZ and the Society for Range Management have as a strength the inclusion of both scientists (theorists) and practitioners (managers). Yet, this has not been fully exploited to deliver either debate or decision making tools, nor has it been used to direct or fund any coordinated research endeavor.

Another matter undermining our professional maturity is the quality of debate at events for both research (congresses) and technology transfer (farmers days). My experience, at most congresses and workshops, is that we are unable to debate, in open sessions, the roots of our discipline. If we are to improve the status of the discipline we need to question, and thus develop sound understanding of the basis of our knowledge.

This can only be achieved by purposefully improving our debating skills. In short, this means we need more constructive 'troublemakers' whose role is to stimulate disturbances and be the devil's advocate. For instance, when scientific publication first began much of the published work was "unrefereed." The peer review was in the form of an open debate via letters in the literature and had the extremely important function of providing a formal record of the development of the theory that became biological or physical law. It may be for this reason that the epistemology of disciplines like physics and chemistry is well established. We may need to consider starting a Journal Of Failed Experiments And Good Ideas with no closed peer review but authors will have to defend their papers in open written debate.
For example, while much effort has been invested in collecting species composition data, in many cases our preoccupation with these data has provided a poor indication of ecosystem responses to impacts of whatever form. Consequently, we have been over-perfecting tools with limited usefulness. This is a critical reason why as a discipline we are not in demand by policy makers or practitioners.

In addition, with few exceptions, decision-support technologies and adaptive management philosophies are very poorly applied or ignored in Africa, so we have failed to translate the theory and knowledge we have into decision support tools.

Changes in the political, and consequently economic, environment in southern Africa has also impacted the discipline in several ways. In particular, two critical issues (redress legislation and research policy) have contributed to the region's widespread decline in the human resource base.

Redress legislation has probably had the biggest direct impact and has resulted in the phenomenon of "white-flight." Several white Africans are now employed in Range Science positions in just about every major range economy, notably Australia, New Zealand and North America. Those that have stayed in Africa have realized that career paths, for white males in particular, are short and many have moved to other pursuits. The irony is because of the multi-skilled nature of the discipline it has always attracted multi-talented people and several scientists have left the discipline to pursue careers in diverse activities ranging from information technology through citrus farming to catering.

Policy directing research in Africa dictates an emphasis on resource-poor farmers, which has resulted in a total shift in focus away from commercial endeavors. As a consequence, several long-term ( $>15$ years) range science experiments have been discontinued because they are perceived to serve commercial agriculture, not resource-poor farmers. Their contribution to an understanding of ecological processes and Range Science is lost.

\section{What Happens Next?}

It is clear that the economies of Africa, especially southern Africa, have shifted enormously during the last five years. Political imperatives have always played a role here and will continue to do so. The environmental lobby on the continent is virtually non-existent but is developing. The most notable example of such action was the vigorous debate around the mineral wealth of Lake St Lucia, now a World Heritage Site. It demonstrated the power of public opinion and a developing awareness of the need to develop sustainability as a culture.

Environmental legislation continues to be refined and many major industrial operations are embracing internationally recognized environmental auditing practices. Many have very sound policies regarding the environment but these are driven by global trade requirements. Nonetheless, this has the potential to serve the discipline well because many such operations are long-term highly exploitative mining operations with major impacts on the environment. Range science has a major role to play here with many "closure programs" having life spans over 30 years.

In addition, the increased emphasis on resource-poor rural economies in many African countries has resulted in greater availability of international funds to uplift such economies. Many countries, such as Eritrea, have national food security policies, and because many have pastoral economies, much of the effort should involve range scientists. This means that universities must include socio-political training in their curricular to equip students to deal with both the biological and human challenges.

Government as well as independent research and development agencies must develop trans-disciplinary (i.e. wholly integrated decision-making groups) teams including experts able to deliver across the sociological-political-economic-range science spectrum. The traditional integrated training provided for multi-talented range scientists will hopefully stand them in good stead to lead such teams. 


\section{Strategies For The Future}

As a science, range science in Africa is underdeveloped. This is being addressed by societies like the GSSA, particularly through specific focused debates at its annual congress. In addition, a multimedia approach is being applied to its publications to improve distribution of information. However, these efforts will be lost if they are not accompanied by a vigorous effort by the discipline's research and academic leaders in the region to adapt to the new socio-economic and political environment. Several strategies are possible. As a budding troublemaker, I suggest:

- We must recognize that traditional modes of working must be overhauled to service client-based funding.

- Using modern statistical tools, we should analyze or reanalyze hundreds of research-years of data collected by several agencies. This would be inexpensive relative to the new knowledge about long-term effects that it would generate, and it would provide inexpensive training opportunities for learner scientists while improving our decisionsupport capacity.
- Professional rangeland society executives should actively attempt to convince employers that their staff should attend congresses to gain in-service training. Congress organizers will facilitate this by including anthropologists, economists, and development sociologists as well as broader environmental science groups and skill-specific workshops.

- Develop partnerships with local business and governments for short-term funding opportunities and improve awareness of the range science discipline in the minds of policy makers, funding agencies and the public at large. In southern Africa this will be a demanding task as the role of scientists and other technology specialists is usually overshadowed by political nicety as demonstrated by the HIV/AIDS debate.

- Using all means possible, encourage black students to pursue range science. Black students generally train in nonagriculturally related disciplines because they associate agriculture with rural poverty. Further, redress legislation has accelerated promotion beyond the ability and experience of several incumbents, which will weaken the range discipline further because much of the long-term institutional wisdom is no longer available to guide this new generation of leaders.

None of these activities will succeed in isolation. We need to exploit the integrative training we have and use these tools to shape the future of the discipline worldwide in a holistic fashion. A review of the classically technical disciplines such as engineering will show that for nearly a decade they have been modifying their approach to training and problem solving. They have assigned up to $10 \%$ of the curriculum as a compulsory non-engineering component to provide training in the skills of integration. Range science would be well advised to formalize partnerships with such professionals to play an active role in transdisciplinary teams developing Africa.

Authors Note: The opinions expressed here are my own and for which I am responsible, and are offered to contribute to the review of the status of rangeland science in Africa. In formulating my thinking, I have had the privilege of debating with several capable scientists and students, and I acknowledge their contribution to my endeavors.

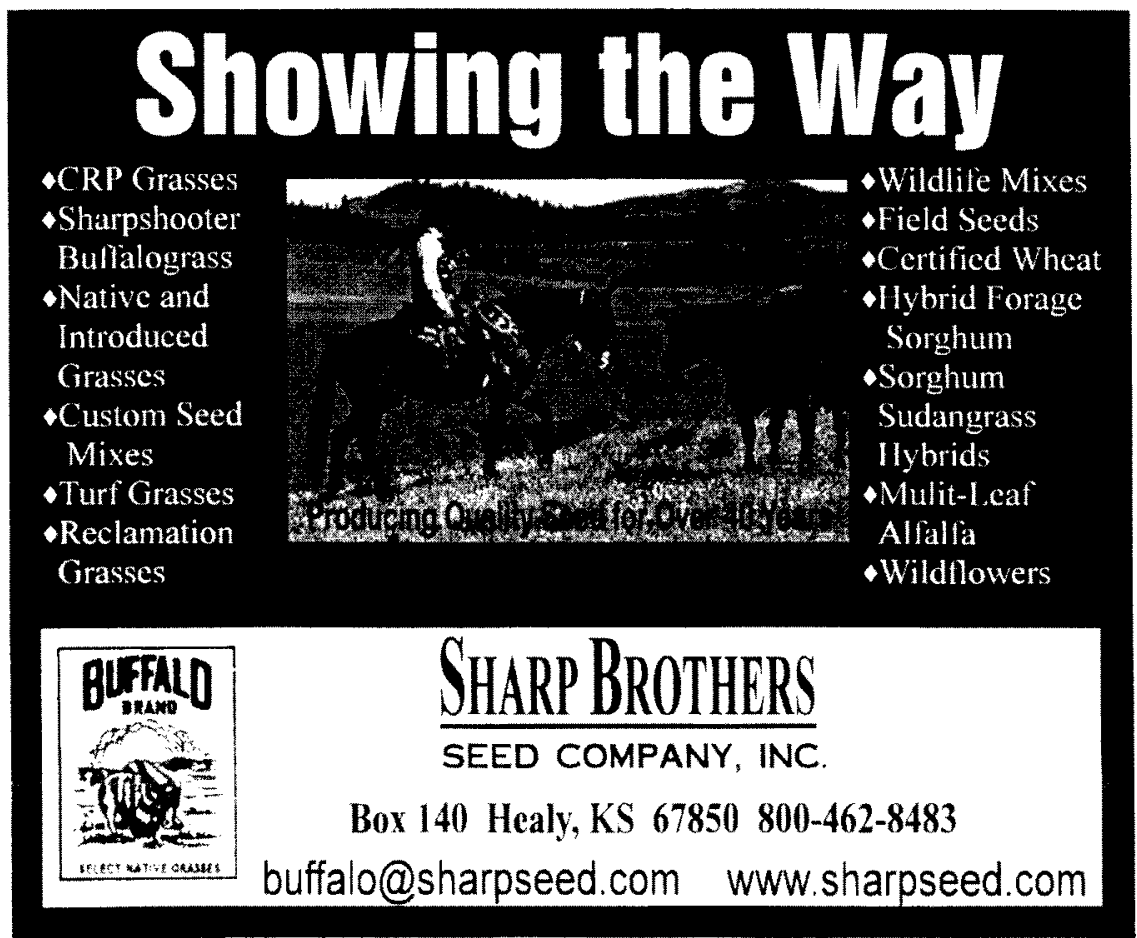




\title{
Eighth In A Series
}

\section{Issues Challenging Rangelands Down Under}

\section{The future of range management in Australia hinges on taking a holistic, regional approach and continuing to attract people to the profession.}

\author{
By Andrew Ash and Mark Stafford Smith
}

Respectively: CSIRO Sustainable Ecosystems, Private Mail Bag, Aitkenvale, , QLD 4814 and CSIRO Sustainable Ecosystems, PO Box 2111, Alice Springs, NT 0871, Australia.

Over $70 \%$ of Australia is rangeland. This vast area of rangelands has a great diversity of ecosystems from arid shrublands and grasslands to semi-arid woodlands and sub-tropical and tropical savannas. The rangelands are an important part of Australia's social and cultural history for both indigenous and non-indigenous peoples,

This rich history, particularly the more romantic pioneering elements, led to a strong affinity of urban communities for rangelands. However, in recent decades the empathy of city dwellers for rangelands and their people has been declining largely because of Australia's trend towards urbanization and globalization.

Although the primary land use in the rangelands is pastoralism, its economic contribution of about ASI billion annually is considerably less than that of mining (AS14 billion) and tourism (AS2.2 billion). However, rangelands also provide other important non-economic values, including high species diversity, unique habitats and traditional hunting and gathering by indigenous peopleswho account for $18 \%$ of rangeland residents and own over $20 \%$ of the area.

The Australian rangeland profession is unlike those of the USA and South Africa, which have a long history of scientific endeavor in rangeland management. Australia's rangelands were scientifically ignored for a considerable part of our agricultural history as most effort focused on agronomic solutions based on European farming practices and overcoming the limitations of Australia's relatively infertile farming lands and variable climate. There were

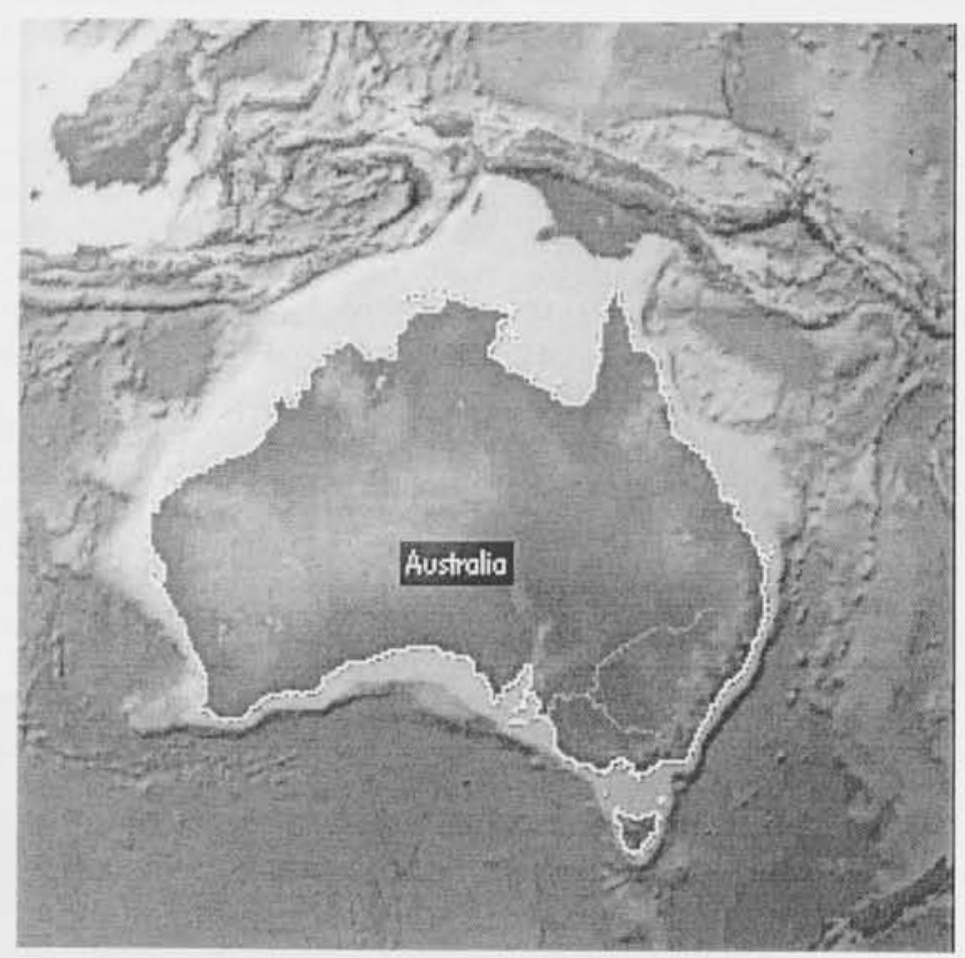

no formal rangeland schools as agricultural science dominated most Australian universities. The best articulated calls for a more formal approach to rangeland management came from a government scientist, Francis Radeliffe, as late as the 1940s when concepts of range science had long been established in the US.

The Australian Rangeland Society was formed in 1975 to provide an organizational framework that would allow the few professionals working in rangelands to exchange ideas and develop a more structured approach to tackling issues in rangeland management. About the same time, more formal teaching of rangeland science was occurring in a couple of universities, usually within Botany departments.

While this late genesis of a professional rangeland society within Australia has meant that we still have a relatively limited biophysical, economic, social and cultural understanding of rangelands, it has not led to entrenched views or paradigm paralysis. For example, the Australian rangeland profession was not tightly bound to Clementsian views of plant succession versus models based on non-equilibrium theory, and so was more easily able to discuss and debate the proposed new paradigms. Also, while the Australian rangeland profession is numerically small it has a diverse array of interests beyond the traditional focus on 
livestock grazing management. These diverse interests have been reflected in special issues of The Rangeland Journal, Proceedings of the Biennial Conferences of the Australian Rangeland Society and the International Rangeland Congress held in Australia in 1999.

\section{Australian Rangelands Today}

There are a number of issues and problems facing Australian rangelands and their communities today. Some of these stem from past management mistakes while others are a result of rapidly changing economic and social values both within Australia and globally. The most important of these contemporary issues are: (1) Land degradation and species loss; (2) Feral animals and weeds; (3) Declining pastoral industry economics; (4) Accommodating multiple land uses (pastoralism, tourism, aquaculture etc); (5) Intensifying rangeland use to remain economically viable; (6) Changing land tenure and access insecurity, which is a particular issue for indigenous, pastoral and mining communities; (7) Structural and social problems at the regional scale in rangelands - these are not just internal issues but are closely tied to decisions made by governments, large corporations and banks in big cities in Australia and overseas; (8) A disconnection between the urban communities and the rangelands - more than $80 \%$ of Australia's population now lives within $50 \mathrm{~km}$ of the coast; (9) The urban communities demanding sustainable use of the rangelands; and (10) International market pressure to attain "green" accreditation and have a well defined and implemented environmental management systems framework in place.

Likely future drivers of rangeland change include: (1) Increased marginalization of rangelands in world and national affairs; (2) Institutions (government and community organizations) playing a key role in shaping rangeland societies and rangeland productivity rather than individual enterprises and market forces; and (3) Energy politics, technology and trade significantly influencing rangelands in the next 200 years.

\section{How Should These Issues Be Addressed?}

In dealing with problems in the past such as land management, pests, weeds and economics, the traditional response from the rangeland profession has been, "We need more and better information." This has led to more research, usually biophysical, but many of the problems remain. Some of this can be attributed to undertaking research at a spatial scale that is not very relevant to management. This is a particular problem in rangelands in Australia because of their extensive scale of management and their heterogeneity.

So, while we have collected much good information and improved our understanding of soil, plant and animal processes at small scales we have had difficulty in translating this understanding to assist management at larger scales. In addition, there has been an increasing trend in recent years to applied research with a decrease in emphasis in strategic research, which is likely to provide greater benefits in the medium to long-term.

Assuming there is enough biophysical understanding, the next solution to solving management problems has been, "We need more and better extension and better integration of existing information." This philosophy has been adopted and applied by various institutions and agencies with the belief that by emulation of successful enterprises in the region many current problems will be solved.

However, the reason many current problems still exist is due to economic, cultural, social and institutional constraints. These constraints are generally beyond the influence and traditional interests of research, development and extension agencies and professionals in the rangelands.

1) Holistic Approach Needed. We believe the key to addressing current and future rangeland problems is a more holistic approach that integrates ecological, economic, social, cultural and institutional issues using a multidisciplinary approach. The traditional technocentric and reductionist paradigm that has been so popular in the past cannot on its own deliver the range of complex solutions necessary to address the current needs of rangelands. While the more traditional biophysical ecological and production research and extension still has much to offer, it will only be of value if it is undertaken at appropriate scales and only if it interacts with socio-economic and institutional systems.

2) Address Issues By Region. Issues should be addressed in a regional context. This is important for two reasons: (1) There is strong evidence that a participatory approach building strong partnerships between key regional stakeholders is a successful means of achieving more sustainable and equitable resource use in rangelands; and (2) National rangeland policies that are set in a regional context rather than assuming that the rangelands are biophysically and socio-economically uniform are likely to lead to better environmental, economic and social outcomes. This would require giving private enterprise freedom to pursue profit where the environment is resilient but provide greater public control where private interest may not produce socially and ecologically desirable outcomes.

Presently, the greatest constraint on coordinated action in rangelands in Australia derives from the fact that these lands spread across five political jurisdictions, with top priority in none. Thus a pre-requisite for future rangelands research may well be the establishment of some cross-jurisdictional forum to focus on rangelands. The other alternative is that future research will really be in the context of regionalization with no special recognition of these regions rangeland nature.

3) Attract Professionals To Rangelands. There is a clear recognition among most rangeland professionals that these approaches are the way of moving forward. However, there has been a significant decline in the number of rangeland professionals in Australia over the last 10 years, both in state and federal agencies. So at the same time we need to broaden our disciplinary approach to addressing rangeland problems, national and state governments are reducing their efforts in the rangelands.

This reduction in effort in the rangelands reflects a broader decline in rural 
towns in Australia, compounded by the withdrawal of government and non-government services. As the rural towns become less attractive places to live, it becomes difficult to recruit professionals into the rangelands.

In a positive move to overcome the decline in rangeland professionals, a new educational initiative called Rangelands Australia has been put in place. Rangelands Australia is a national initiative to provide a cooperative approach to education, training and research for the betterment of Australia's rangelands and its communities. The focus for the implementation of
Rangelands Australia is through the establishment of a center of excellence in rangeland management education, training and research located at the University of Queensland Gatton Campus with a nationwide network of rangeland centers and online services.

The regional, multi-disciplinary approaches needed to provide rangeland solutions are starting to be adopted by rangeland professionals. However, for these approaches to become more widespread the individual skills of our rangeland professionals needs to broaden; we need ecologists with better business skills and appreciation of the socio-eco- nomic environment in which they work, social scientists who understand rangeland ecology and production systems, and we need teams with a diversity of skills who can work well together. Rangeland professionals must also be more politically astute if we are to influence policy to overcome some of the institutional constraints that bedevil the range.

\section{Acknowledgements}

Many thanks to Guy Fitzhardinge, Margaret Friedel, David Eldridge, Ron Hacker, David Freudenberger, Jim Noble and Rob Richards for providing many of the ideas expressed in this paper.

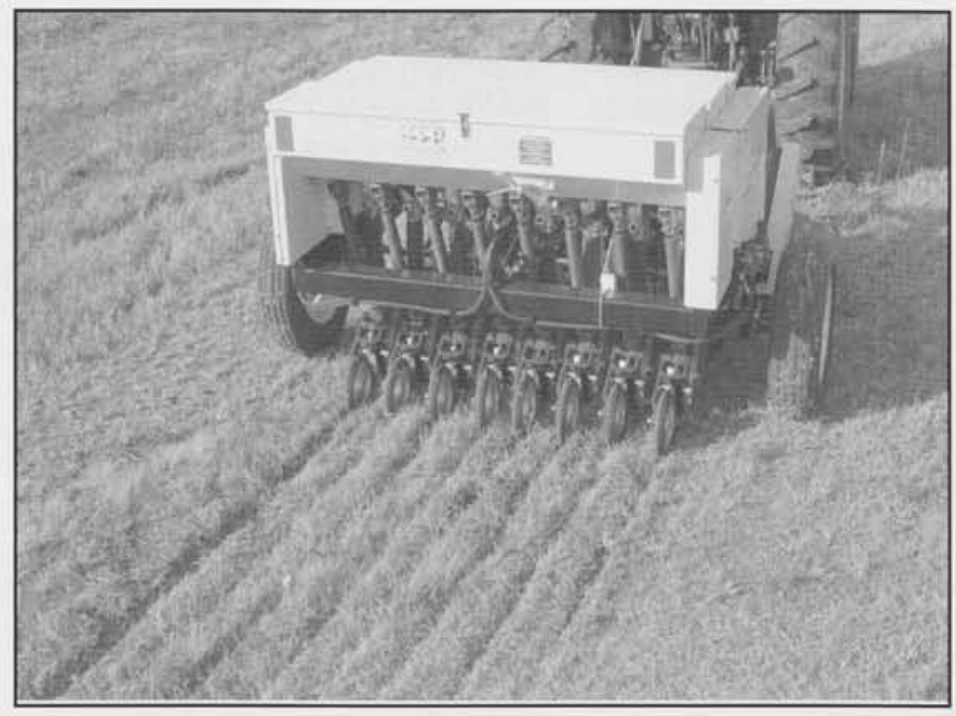

N14 WV 9 The "Trillion" - shown at right, is the ideal 1 D broadcast seeder for wildflowers, turf grasses, and fluffy/chaffy prairie seeds. Unit has three types of seed boxes and combines the truax seed delivery system with two Brillion cultipack rollers.
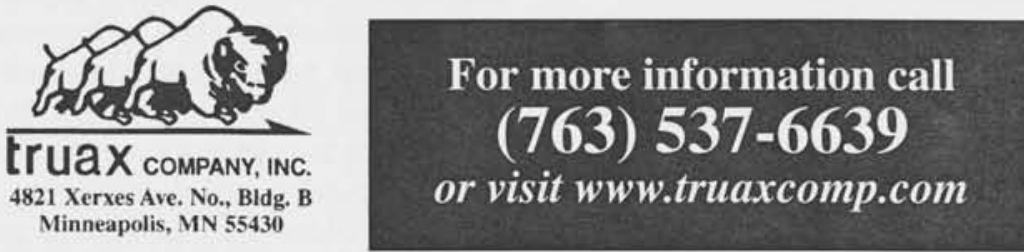

\section{PERFORMANCE.}

Superior design, top-quality materials, and meticulous hand-built construction are what set truax seeding equipment apart from the competition. You'll find these in every truax seeder from the small, hand-cranked, Seed Slinger that lets you broadcast fluffy seeds and grasses together by hand, to the famous Flex II seed drill pictured at left, which interseeds native grasses, turf grasses, fluffy seeds, small grains, wildflowers, even legumes.

The result is outstanding seeding performances even in the most challenging environments! - and durability that will last for decades.

If you want dependable seeding performance, you want a truax!

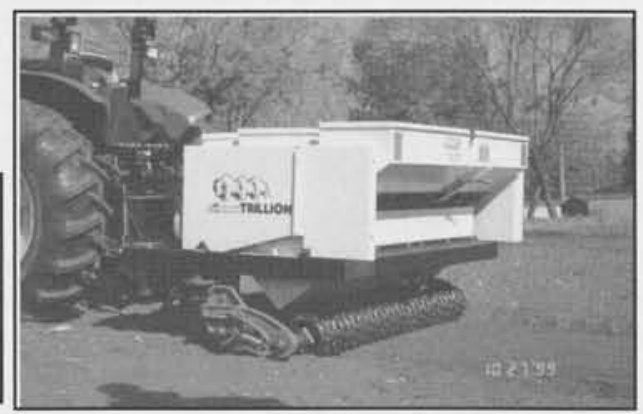




\title{
Ninth In A Series
}

\section{The Future Role of Range Management Professionals: A Canadian Perspective}

\section{Tomorrow's range management professionals will be faced with increasing public participation and scrutiny of rangeland uses. How should they adapt?}

\author{
By Michael Pitt and Arthur Bailey
}

\begin{abstract}
Respectively, Faculty of Agricultural Sciences, University of British Columbia, Vancouver, B.C. Canada V6T 1Z4; Department of AFNS, University of Alberta, Edmonton, Canada T6G 2P5.
\end{abstract}

Predicting the future is both challenging and risky. Our approach is to first review some of the past and the present in order to interpret likely trends for the Canadian range management profession.

Aboriginal peoples were Canada's first range managers. They existed for centuries on the Canadian plains and intermountain West utilizing the natural plant and animal food resources for their purposes. Undoubtedly, both fire and grazing comprised primary tools in their management of rangelands. Recent anthropological works reveal a level of sophistication that has been acknowledged only rarely. These first Canadian range managers learned how to manage the natural resources surrounding them, and they passed this knowledge along through the generations.

The next wave of immigrants to North America were Europeans who brought new plants, new livestock, and new resource management systems. Community leaders and settlers assumed their European ways were appropriate for the new lands. What emerged was an era of exploitation and mismanagement precipitating extreme overgrazing on some rangelands and dust bowls in others.

During the early $20^{\text {th }}$ century, range management emerged as a profession primarily in response to overgrazing in the western United States. The discipline's pioneering approach to wise stewardship based on the grazing ani-

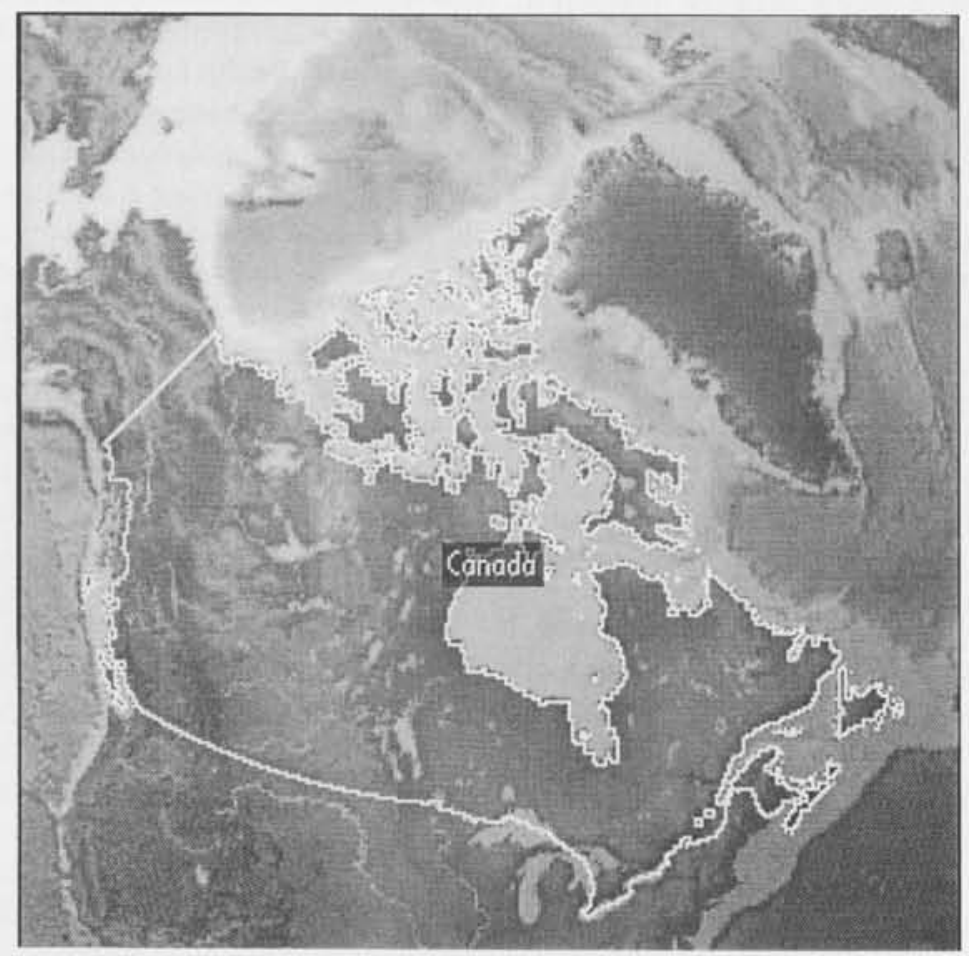

mal as the primary tool of conservation - led to improved environmental and range conditions, particularly after the 1930s. Our status in Canada as a scientific discipline grew quickly following the formation of the Society For Range Management in 1948.

The beginnings of range management in Canada developed for similar reasons on the central plains and intermountain regions. Since there is more forest than natural grassland in western Canada, there has been a considerable emphasis within the discipline on understanding the management of grazing by wildlife and livestock on forested rangelands. Most of these forest ranges are on crown (public) land managed under provincial, multiple use policies that recognize the needs of many resource users on a common land base. Canadian range management unfolded more slowly than in the United States, but enjoyed continued success from the 1950 s through the 1980 s, and in many cases also through the 1990 s. 


\section{Cultural and Economic Change} and the Environmental Movement

The second half of the $20^{\text {th }}$ century was a period of rapid technological and sociological change. New industries and new wealth developed in the cities rather than in rural areas. Economic opportunities and people moved away from agriculture to light industry and service sectors in urban centers. Rachel Carson's book Silent Spring alarmed urban activists regarding the effects of a technological society on the environment. As these social changes occurred, the balance of economic and political power also shifted from its agrarian base in rural areas towards urban-based industries and voters. In a few decades the rural-dominated political power structures have been largely replaced. Beneficiaries of these social changes include the various urban-based environmental lobby groups.

Increasing urbanization distanced and virtually eliminated the public's personal familiarity with natural resource management. During this time, the range profession found itself placed on the other side of the fence in terms of its perceived relevance to conservation and stewardship issues by these new and vocal public lobby groups. Many range managers, because of their association with livestock grazing, began to be perceived as part of the problem rather than part of the solution. Our profession's initial, and in some areas, continuing, defensive reaction to these social changes brought further alienation between range management professionals and the multi-publics that we serve.

Since control of Canada's natural resource policies lies primarily with each province rather than with a distant federal government, policies affecting rangelands are changing rapidly to reflect the concerns of urban dwellers. For example, in British Columbia, most of the population now resides in urban areas and Canada's most influential environmental groups are also headquartered in this western-most province.

In northern regions, and other areas far from the large cities, change in land use and range policy has not been as widespread. Rangeland management policy of the Prairie Provinces generally remains under stronger agrarian influence. Rural ranching remains a viable industry, particularly where rangelands are well managed. More changes will eventually affect these areas, however in response to urban concerns.

For example one study in the USA revealed that California ranchers believe that society is becoming hostile to ranching (Liffmann et al. 2000). Most ranchers identified the following issues as serious or extreme threats to ranching: wilderness designations, regional planning, endangered species legislation, animal rights, closure of open range, environmentalism, water quality standards, and urbanization. In western Canada these pressures vary greatly and are most pronounced in southern British Columbia closer to the influence of large urban centers, and Rocky Mountain foothill rangelands near Calgary. Such changes in the way that society views resources and their uses will continually force Canadian range managers to rethink the growing demands on resources and rangelands.

Another example of shifts in societal views can be observed from how the foot-and-mouth epidemic was handled in rural Britain. To stop the spread of this disease, tourist access to the countryside was substantially restricted, causing extensive financial loss to the rural tourism industry; however, resistance within the non-agrarian rural interests to these closures has gradually risen, and some commentators speculate that this likely represents the last time agriculture successfully lobbies the government to shut down the countryside. During the next crisis, tourism and recreation may be too valuable and too powerful to allow such a closure.

\section{Preparing For The Future}

How long will it take before the urban public holds a similar perspective towards use of rangelands in western Canada? To prepare for these changing social views, range managers must examine the following questions:

\section{1) Who do we serve?}

As range management professionals, we must remember we serve first the rangeland resource. Secondly we serve the publics that rely upon our expertise.
Lastly, we serve our personal interests. These truisms have always been, and will always remain so.

The key emphasis is upon the resource rather than upon any one user of the resource. As our profession matures, there will be a greater diversity of users of rangelands and all users will periodically need the expertise of range management professionals.

The diversity that is Canada will continue to increase. To adapt to that diversity, change in range education will be inevitable. The ecology-based discipline of range management fits more closely to the umbrella of natural resource disciplines than to the biotechnology-and genetics-laden intensive agriculture of the future. We expect a greater diversity of rangeland users in the future and thus we also expect a greater diversity of students.

In the future, more urban-born students will enroll in range management classes without having seen a range or a ranch. Nonetheless, the range management students of the future will share a great deal with their colleagues of 20 , or even 50 years ago. They will be genuinely interested in conservation and wise stewardship and will also respect the entrepreneurial skills and unique perspectives of the ranching community. Because of their background, many of these students will be better prepared than their predecessors to deal with the challenges of an urban society that has the political clout to revise resource management policies.

Tomorrow's student will bring a cosmopolitan sophistication that recognizes sustainable range management needs much more than knowledge of rest-rotation grazing or the ecological role of rangeland fires. This young person will generally accept that tomorrow's solutions require broadly-educated, rangeland professionals with communication skills, objectivity, ecological knowledge, empathy for rural and urban priorities, an ability to facilitate and profit from conflict, and a passion for achieving solutions to complex problems.

2) What do we want to be?

The Society for Range Management should continue its primary role as an organization of resource expertise. As much as possible, SRM, and future 
range management professionals, should ensure that its "cult of values" continues to expand to include a broad spectrum of values.

Range professionals must accept that the interests and needs of our society continue to change whereas certain tenets never change. Wise stewardship of rangeland resources is a permanent tenant for all range management professionals, now and in the future. Nevertheless, the users of rangelands will vary among regions, ecosystems, generations, and cultures. Each generation of range professionals must adapt to, and communicate with, the multifaceted society of their day.

Future range professionals will require the technical knowledge of the day, but must also be skilled socially and politically. Above all, rangeland professionals must be sincerely and openly receptive to differing points of view, and to differing values.
A few range management professionals will be regarded with sufficient esteem by all parties that they will be sought out to play a mediatory role between opposing resource interest groups. These few range management leaders will be knowledgeable regarding rangeland resources. They will also be skilled communicators able to mitigate among widely divergent points of view and values to such a degree as to reconcile differences between parties without compromising the basic tenets of sustainable rangeland management.

The modern range management professional must deal with ever increasing complexities due to global pressures, environmental issues, special interest groups, explosion of information and technology, and public awareness. Although technical skills will always be essential for range management professionals, an ability to think critically and to synthesize information are far more important than the mere acquisition of information that doubles every few years, and often becomes quickly outdated.

The urban public will continue to scrutinize range management professionals intensely. More than ever before, range professionals will be required to defend their decisions, and to communicate their decisions clearly to a wide variety of publics who have a genuine, legitimate interest in public resources.

Conservation of rangeland resources constitutes a primary goal of the Canadian range management professional at the beginning of the $21^{\text {st }}$ century. The greatest difference with the last century will be the amount of public participation and scrutiny.

\section{References}

Liffmann, R.H., L. Huntsinger, and L.C. Forero. 2000. To ranch or not to ranch: Home on the urban range? J. Range Manage. 53:362-370.

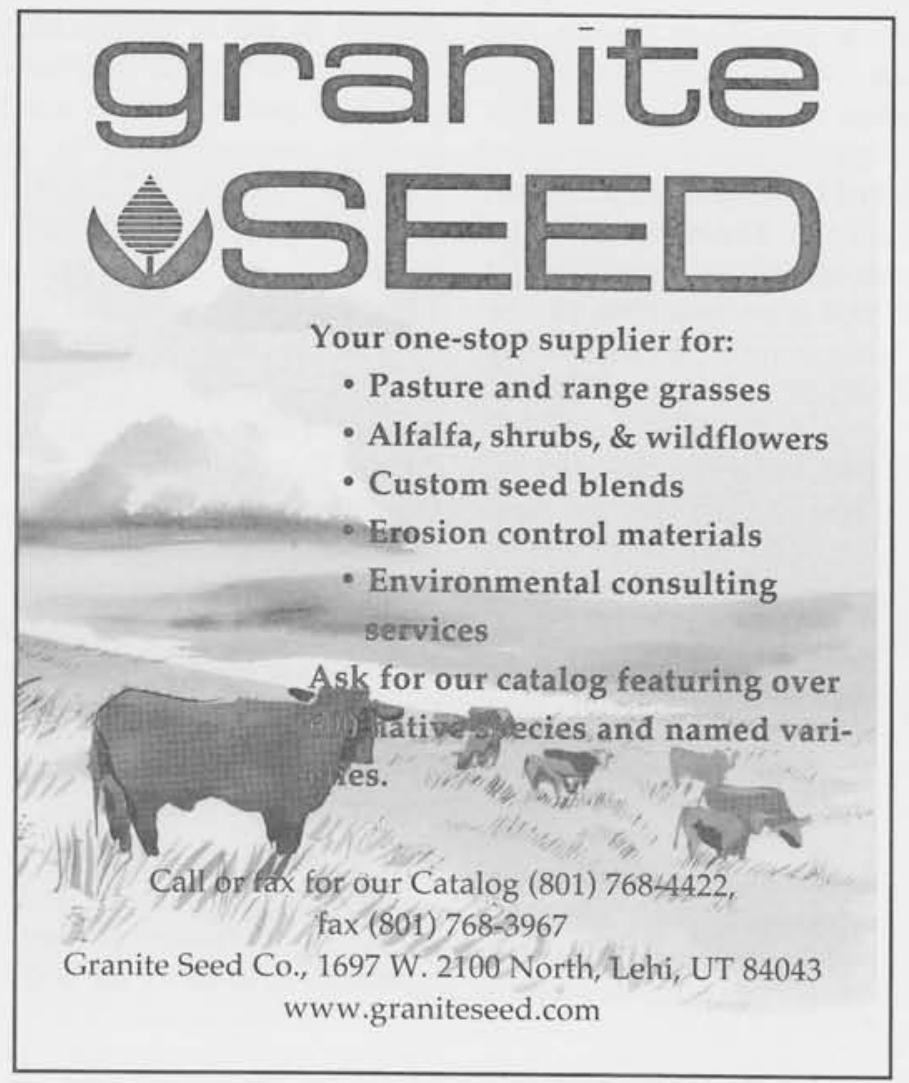




\title{
Viewpoint
}

\section{Using The Preferred Grazing System}

\author{
By Marion E. Everhart
}

The "Preferred Grazing System" was developed in 1955 by Everhart and Swartz. For 45 years, Marion E. Everhart, certified range management consultant with SCS, USDA and Ralph Swartz, soil scientist, SCS, studied ranges all over West Texas and made extensive studies of air-in-the-soil. Everhart is a graduate of Ft. Hays State University, Hays, Kansas, and has worked in all of the western states.

The "Preferred Grazing System" they developed is the only known system that provides for the true and full carrying capacity of all ranges from the high mountainious areas to lowlying pastures throughout the United States. It involves using " 41 " plants and their "preference ratings" in appropriate land resource areas where the role of air-in-the-soil assists plant growth.

Most livestock ranchers have sketchy knowledge of the role of air-in-the-soil, and the fact that good air movement is necessary for soils without which much of the annual precipitation is lost for plant growth. Consequently the land becomes more arid and dry with less plant density. Even annuals will have a hard time growing because of lack of air in the soil. That is why it is so important to have knowledge of the role of the " 41 " species of range plants.

The first article entitled "Preferred Grazing" was published by SRM in Rangelands, Vol. 13, No. 6, December 1991. (A reprint can be obtained by contacting the author.) The first item that must be considered is that more livestock can be grazed on a given area if provision is made for the timely movement of livestock from one pasture to another with consideration of the stage of growth of the vegetation. Before initially stocking a range at what is believed to be full carrying capacity, try "preferred grazing" where one can vary the number of livestock at the time of rotation of the pasture by adding to- or taking from - the initial number. Give consideration to the fact that livestock are now going to eat " 41 " species instead of 2 or 3 as is the case of continuous use grazing. Also consider that the air-in-the soil factor is now in effect thus providing for an increase in plant growth because of an increase of a healthy soil environment by providing organic and humus rich soils.

Once one begins with a "preferred grazing" plan, if more grass is needed for your livestock, all that needs to be done is to open the gate to the next pasture. Because livestock are now grazing " 41 " instead of 2 or 3 species of vegetation and because air is getting into the soil creating humus rich soil thus increasing the carrying capacity-soon more grass will be left over at the time of rotation. Then consideration can be made of the possibility of adding more livestock. With "Preferred Grazing" cattlemen can examine all the livestock every time they rotate the pastures. "Grow before you graze" is an axiom of preferred grazing. Seldom can the true carrying capacity be known ahead of time. It takes all sizes of vegetation-from "short," "medium" to "tall" to make up the total true carrying capacity for the " 41 " species. For the first time in years, livestock cannot see their noses with preferred grazing and its use of 41 species, instead of 2 or 3 species, also full use of air-in-the-soil. Livestock get a taste of all of the preferred species-this is true biodiversity. Under continuous grazing, livestock graze the most preferred species first and then the lesser desired vegetation second; consequently there is no increase of air-in-the-soil and when the rains come, there is no in soak and the precipitation runs from the land. Temporary fencing such as electric fencing and because of the need for fences to be located as shown in the article published in 1991 - "most of the permanent fencing should be removed." Place watering facilities as shown in this article, and do not fence out "pie" shaped pastures. The "Preferred Grazing System" applies to all sizes, kinds and shapes of rangeland.

Marion E. Everhart is a certified range management consultant and former range specialist with the Soil Conservation Service in Texas. 


\section{Resource Roundup}

\section{A Photographic History}

Changes in the vegetation and landscape of the Northern Great Plains over the last 80 years is documented in a new publication from the USDA's Agricultural Research Service (ARS).

The report profiles three sets of photographs taken at the same locations about 40 years apart at locations in Montana, Nebraska, North Dakota, South Dakota and Wyoming. University of Arizona researchers took the first two sets of photographs between 1908 and 1937 and from 1958 to 1960 . ARS commissioned the third set, taken in 1998.

In addition to the photographs, the report includes historical information on land use, grazing practices and other impacts on the rangeland at these locations over the past 80 years.

ARS reports that the most surprising change noted in the study is an extensive increase in areas densely covered by ponderosa pine on the mountains and by sagebrush in the valley and foothills over the past few decades. The report notes wildfires have been virtually eliminated in many areas. ARS hopes researchers and land managers will utilize this monitoring information to design land-use and grazing strategies that help conserve the long-term productivity of the range.

Range scientists Keith Klement and Rod Heitschmidt, both with the Fort Keough Range and Livestock Research Station in Miles City, MT, compiled the report along with political science professor C.E. Kay of Utah State University.

The report is available in print format from ARS, on on-line at www.ars.usda.gov/is/np/eighty years/eightyyearsintro.htm.

\section{Cattle Like Open Spaces}

When it comes to mineral feeder design, cattle prefer an open feeder, according to a New Mexico State University study.

Cattle will utilize about 30 percent more of a complete salt and mineral supplement when it's in a simple open feeder compared with a covered vane feeder, the study found. Mark Petersen, a professor of range nutrition with NMSU's Agricultural Experiment Station led the study.

Cattle in general don't like to put their heads into an enclosed area, Petersen says. He says this is likely because cattle fear predators and want to spend as little time as possible under a feeder hood where they can't see their surroundings.

He points out that a cover also limits the number of cattle that can feed on the mineral supplement at the same time. Whereas, an open feeder makes the supplement more accessible to several head at one time.

\section{Innovative Ideas From GLCI}

Several states are implementing unique ideas to draw attention to their Grazing Lands Coalition groups and help educate land owners about range management techniques.

In North Dakota, the state coalition has initiated a mentoring program to provide guidance on grazing land management to the next generation of grazing land managers as well as agency personnel. The program, known as the Grazing
Management Mentoring Network, provides the opportunity for less experienced people to work closely with experienced grazing land managers who understand resource management, conservation efforts and other pertinent issues. The "network" includes numerous meetings, training courses and workshops.

In South Carolina, the state Grasslands Conservation Coalition contacted their Governor and proposed naming Indiangrass as South Carolina's official state grass. The purpose behind their idea was to call attention to the grassland resources in South Carolina, as well as establish an identity for the coalition and its purpose of promoting improved grassland management, research, and education to producers and the public.

In August, the Governor signed a bill proclaiming Indiangrass the state grass of South Carolina.

In other GLCI news, Dennis Neffendorf, National GLCI Coordinator, has taken another position with the Natural Resources Conservation Service. Rod Baumberger, previously Northern Plains GLCI Coordinator, has been named the new national coordinator. He will headquarter out of Sturgis, South Dakota.

For more on GLCI visit www.glci.org

\section{Soybean Success Stories}

Three new soybeans can serve as a good transition forage for cattle heading to the feedlot, say researchers at the USDA's Agricultural Research Service. Forage soybeans can be used for hay, silage or grazing and they reduce the need for concentrates as a protein source.

Bred especially for use as forage, the new soybean cultivars are: Donegal, adapted to the Northeast; Derry, adapted to the northern Midwest; and Tyrone, adapted to the South. In good conditions, these cultivars can grow more than 6-feet high.

They can be grown alone or in combination with grass species such as brown midrib sorghum-sudangrass hybrids, corn or pearl millet.

In other soybean research, University of Missouri researchers say feeding whole, unprocessed soybeans to cows in late pregnancy boosts rebreeding rates.

Chris Zumbrunnen, regional extension livestock specialist at Milan, Missouri, reports that in research and on-farm trials, feeding cows 3.5 pounds of whole beans per day for 30 days before calving increased both first-service conception rates and overall pregnancy in beef herds.

"On university farms and on producer farms, we have consistently seen 14 to 23 percent increase in first-service conception rates from feeding soybeans," he says.

In one study, cows artificially inseminated after being fed soybeans had an 86 percent one-time AI conception rate. Cows fed a control diet had a conception rate of just 63 percent. All other conditions, including the AI technician, were the same.

"When 3.5 pounds of beans are added to the hay ration of cows in their last weeks of pregnancy, you get a ration with about 5 percent fat," Zumbrunnen says. While the rebreeding rates were improved, he cautions against feeding higher rates of soybeans. 


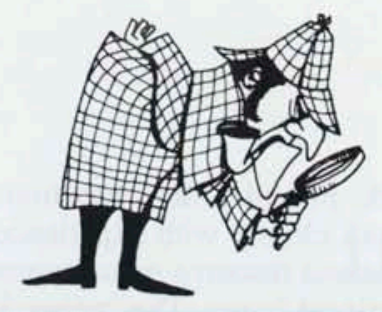

Cull Cow Management And Its Implications For Cow-Calf Profitability

Randall D. Little, Allen R. Williams, R. Curt Lacy And Charlie S. Forrest

Seasonal price lows and deteriorating forage quality in late summer limit returns to cull cows sales in the fall. Partial budgeting was used to determine the potential of cull cow management to boost net returns. Results suggest that spring cull sales, which averaged about $\$ 30$ per cow more and were higher in nine of ten years studied, could increase net returns over fall cull sales. Producers with access to low-cost feedstuffs may have opportunity to increase returns by marketing cull cows in better condition in the spring when prices trend higher, rather than the more typical practice of fall sale.

\section{Seasonal Dynamics Of A Prairie Sandreed Rhizome}

Development

Patrick E. Reece, Jennifer S. Nixon, Lowell E. Moser, And Steven S. Waller

Multiple generations of rhizome connected tillers stabilize soils and produce significant amounts of herbage but little is known about the dynamics of rhizome development. Seasonal relationships between foliar characteristics and rhizomes of prairie sandreed were examined on sand range sites at 30 day intervals from May through September 1989 and 1990 near Scottsbluff, Nebraska. Measurable increases in new rhizomes did not occur until herbage exceeded a threshold of $50 \mathrm{~g} / \mathrm{sq} . \mathrm{m}$. Given the dependence of the grass on vegetation reproduction, deferment may be the only reliable method of obtaining measurable increases in plant populations.

\section{Nutritional Value And Intake of Prickly Pear By Goats}

Zeno McMillan, Cody B. Scott, Charles A. Taylor, Jr. And J. Ed Hustone

Prickly pear species are common throughout the southwestern U.S. and can produce substantial biomass that can be used as emergency forage, especially during droughts. The relative nutritional values of both spined and spineless prickly pear were evaluated. Spineless prickly pear was higher in digestibility and crude protein but dry matter intake was similar for the 2 species. Once a preference for prickly pear developed, goats continued to eat the prickly pear even though other forage was available.

Sneek A Peek

\section{Sneek A Peek} Upcoming Issue Of Of Range Management

\author{
Northern Dry Mixed Prairie Responses To Summer \\ Wildfire and Drought
}

Catherine Erichsen-Arychuck, Edward W. Bork, And Arthur W. Bailey

\begin{abstract}
Information on the resilience of Dry Mixed Prairie to dormant season wildfire in western Canada is limited. A study in southern Alberta following an August wildfire evaluated changes in plant species composition, herbage production, ground cover, and livestock utilization. Recovery was variable in the landscape and took up to 3 years, due in part to several years of drought. Cattle also utilized more herbage on burned areas. These results highlight the prolonged and spatially variable impact wildlife has on arid rangelands and suggests changes in management are necessary to ensure recovery.
\end{abstract}

\section{Herbicide Residues And Perennial Grasses Establishment On Perennial Pepperweed Sites}

James A. Young, Charlie D. Clements, And Robert R. Blank

Perennial pepperweed invasion into native hay meadows is a threat to the range livestock industry of the Intermountain area. Seedling establishment characteristics of tall wheatgrass on sites where perennial pepperweed was controlled with 2,4-D or chlorsulfuron were evaluated near Reno, Nevada. There was evidence of chlorsulfuron residues in the soil for 3 years which prevented grass establishment. Application of 2,4-D at flower budding followed by seeding tall wheatgrass in the fall, and application of low rates of 2,4-D over the wheatgrass seedlings the next spring, gave the best suppression of the weed and grass establishment.

\section{Day And Night Grazing By Cattle in The Sahel}

Augustine A. Ayantunde, Salvador Fernandez-Rivera, Pierre H. Hiernaux, Herman van Keulen And Henk M. J. Udo

Night grazing is a common herd management practice in the West African Sahel. The effects of night grazing on diet selection, forage and water intake, fecal excretion, feeding behavior and performance of cattle was evaluated in Sadore, Niger. Grazing exclusively in the night cannot substitute for day time grazing, but can be used as a complementary practice. Timing (day or night) of grazing did not affect diet selection but nocturnal grazing decreased the need for water. 


\section{Bud Viability In Perennial Grasses: Water Stress And Defoliation Effects}

Andrea C. Flemmer, Carlos A. Busso And Osvaldo A. Fernández

The ability of perennial grass plants to withstand defoliation under water stress is a major factor in determining their competitive ability. Field studies evaluated the effects of defoliation and water availability at different growth stages in 3 perennial grasses from the temperate rangelands of Argentina. Responses of axillary buds were in general specific to the species and treatments, sampling time and cumulative effects of previous treatments. Response predictions of these species under natural field conditions is difficult where they are often defoliated under water stress.

Intensive-early Stocking For Yearling Cattle In The Northern Great Plains

\section{E.E. Grings, R.K. Heitschmidt, R.E. Short, And M.R. Haferkamp}

Declining forage quality and quantity in late summer can limit weight gains of yearling cattle grazing this forage. A 3-year study evaluated summer grazing strategies for yearling steers on Northern Great Plains rangeland. Steers in intensive early stock pastures gained less weight during the early season grazing period than did those in season-long stocked pastures but gain per hectare was greater in the intensive early stocked pastures. Intensive early stocking with growing steers may be a viable means to overcome limited forage quality during late summer and to maximize forage utilization in years of abundant forage.

\section{Evaluating The Ecological Relevance Of Habitat Maps For Wild Herbivores}

\section{Marc E. Stalmans, Ed T.F. Witkowski And Kevin Balkwill}

Management of large wild herbivores depends on understanding habitat availability and suitability. Remote sensing using LANDSAT 5 TM image was used to quantify and map the distribution of sour and mixed grasslands in the Songimvelo Game Reserve, Mpumalanga, South Africa. The qualitative difference between mixed and sour grasslands overrides quantitative differences in forage availability, fire history and human disturbance in influencing herbivore distribution. The integration of field data and satellite imagery into a GIS system offers a powerful tool for objective quantification and mapping of available habitat.

\section{Seed Longevity And Seeding Strategies Affect Sagebrush Revegetation}

\section{Terrance Booth}

Sagebrush and other xerophytic shrubs are legally mandated components of revegetation for reclamation of coal-mined lands in Wyoming. The fourwing saltbush "exclusion" and "pioneer" revegetation hypotheses were evaluated on fresh-stripped and stored topsoil through 4 post-seeding growing seasons in northern Wyoming. New sagebrush seedlings were detected annually but seed efficiency, and seedling density and height were not affected by topsoil source. Proper pre-sowing fallow and mixed-species seeding strategies have a great influence on shrub revegetation success whether or not the topsoil has been stockpiled for $\leq 5$ years.

Vegetation Responses Following Wildfire On Grazed And Ungrazed Sagebrush Semi-Desert

Neil E. West And Terence P. Yorks

In light of the concept of state-and-transition for assessing rangeland succession there is much confusion as to both the validity and the implementation of the ideas. We examined the changes that occurred over 20 years in vegetation cover and bare soil in a sagebrush semi-desert area in Utah following a wildfire. Distinct differences in total plant cover, growth form, and species composition were found between burned (grazed and ungrazed) and the unburned and grazed areas. While the state-and-transition model allows greater flexibility in depiction of changes consequent to management action, it does not apply everywhere.

\section{Elk Management Stratgies And Profitability Of Beef Cattle Ranches}

Wendy L. F. Torstenson, Michael W. Tess, And James E. Knight

Because private lands, primarily livestock ranches, provide an important part of annual elk habitat, cattle-elk interactions are important to public resource managers and livestock producers. Computer simulation was used to model 5 western Montana ranches, estimating the effects of elk populations on ranch profitability, and evaluating 3 strategies to recoup costs associated with elk. Results showed that providing elk habitat on private lands does represent an economic cost to ranches. However, Montana ranches represented by our sample can recover most, if not all, of these costs by implementing one of the management strategies studied.

Perspectives On Water Flow And The Interpretation Of FLIR Images

\begin{tabular}{|l|}
\hline S.L. Larson, L.L. Larson, and P.A. Larson \\
\hline Airborne infrared thermal radiography has been proposed as a tool for monitoring \\
temperatures of streams and rivers. Two methods were used to evaluate this technique \\
for monitoring water temperatures. The analysis shows that this interpretation of the \\
data is in error. Airborne monitoring of water temperatures should be thoroughly eval- \\
uated and tested against direct stream temperature measurements before being used to \\
enforce regulatory policy.
\end{tabular}




\title{
Browsing The Literature
}

\author{
Jeff Mosley
}

This section reviews new publications available about the art and science of rangeland management. Personal copies of these publications can be obtained by contacting the respective publisher or senior author (addresses shown in parentheses). Suggestions are welcomed and encouraged for items to include in the future issues of Rangelands.

\section{Animal Ecology}

Escherichia coli 0157:H7 in free-ranging deer in Nebraska. D.G. Renter, J.M. Sargeant, S.E. Hygnstorm, J.D. Hoffman, and J.R. Gillespie. 2001. Journal of Wildlife Diseases 37:755760. (College of Veterinary Medicine, Kansas State Univ., Manhattan, KS 66506). E. coli was present in the feces of 4 white-tailed deer out of 1,426 deer tested.

Mule deer foraging preference among five sagebrush (Artemisia L.) taxa. C.L. Wambolt. 2001. Western North American Naturalist 61:490-494. (Dept. of Animal \& Range Sciences, Montana State Univ., Bozeman, MT 59717). Mule deer readily consumed sagebrush in winter, exhibiting only slight preferences among mountain big sagebrush, Wyoming big sagebrush, threetip sagebrush, and low sagebrush. Basin big sagebrush was less preferred.

Precipitation and desert bighorn sheep in the Mazatzal Mountains, Arizona. T. McKinney, T.W. Smith, and J.D. Hanna. 2001. Southwestern Naturalist 46:345-353. (Arizona Game and Fish Dept., 221 W. Greenway Rd., Phoenix, AZ 85203). Desert bighorn sheep populations fluctuated with the amount of annual and seasonal rainfall.

\section{Improvements}

Short-term impacts of prescribed fire on a rodent community in desert grasslands. C.S. Fitzgerald, P.R. Krausman, and A.L. Morrison. 2001. Southwestern Naturalist 46:332337. (P.R. Krausman, School of Renewable Natural Resources, Univ. of Arizona, Tucson, AZ 85721). Rodent communities did not differ in size or species richness between burned and unburned areas.

\section{Management Planning}

Making watershed partnerships work: A review of the empirical literature. W.D. Leach and N.W. Pelkey. 2001. Journal of Water Resources Planning and Management 127:378-385. (Dept. of Environmental Sci. and Policy, Univ. of California, Davis, CA 95616). Reviewed 37 studies and identified 210 practical suggestions for designing successful collaborative planning groups.
Roles of research scientists in natural resource decisionmaking. T.J. Mills and R.N. Clark. 2001. Forest Ecology and Management 153:189-198. (U.S. Forest Service, Pacific Northwest Research Station, P.O. Box 3890, Portland, OR 97208). Discusses the lessons learned from the interaction among scientists and natural resource decision-makers in the Interior Columbia Basin Ecosystem Management Project.

Towards participatory environmental management? I. Kapoor. 2001. Journal of Environmental Management 63:269279. (Faculty of Environmental Studies, York Univ., 4700 Keele St., Toronto, ON M3J 1P3, Canada). Concludes that many questions remain about whether local participation in environmental management can be widely institutionalized.

\section{Plant/Animal Interactions}

Effects of migratory grazers on spatial heterogeneity of soil nitrogen properties in a grassland ecosystem. D.J. Augustine and D.A. Frank. 2001. Ecology 82:3149-3162. (Dept. of Biology, Syracuse Univ., Syracuse, NY 13244). Wild ungulate grazing altered the distribution of soil nitrogen across grassland landscapes in Yellowstone National Park.

Long-term influences of livestock management and a nonnative grass on grass dynamics in the desert grassland. D.L. Angell and M.P. McClaran. 2001. Journal of Arid Environments 49:507-520. (School of Renewable Natural Resources, Univ. of Arizona, Tucson, AZ 85721). Total grass density was unaffected by livestock grazing intensity, although bush muhly responded favorably to summer rest periods.

Seedling recruitment in Oryzopsis hymenoides: Are desert granivores mutualists or predators? W.S. Longland, S.H. Jenkins, S.B. VanderWall, J.A. Veech, and S. Pyare. 2001. Ecology 82:3131-3148. (USDA-ARS, Univ. of Nevada, 920 Valley Rd., Reno, NV 89512). Rodents harvested a large majority of Indian ricegrass seeds, and rodent seed caches enhanced seedling establishment.

\section{Plant Ecology}

Eighty years of vegetation and landscape changes in the northern Great Plains: A photographic record. K.D. Klement, R.K. Heitschmidt, and C.E. Kay. 2001. USDA Agricultural Research Service Conservation Research Report No. 45. (USDA-ARS, Fort Keogh Livestock and Range Research Lab, RR1 Box 2021, Miles City, MT 59301). Few changes had occurred on the 42 sites other than: 1) an increase in woody plants, 2) an increase in non-indigenous plant species, and 3 ) conversion of some sites to croplands and roads. 
Exotic plants in early and late seral vegetation of fifteen northern Rocky Mountain environments. T. Weaver, D. Gustafson, and J. Lichthardt. 2001. Western North American Naturalist 61:417-427. (Dept. of Ecology, Montana State Univ., Bozeman, MT 59717). All disturbed sites were susceptible to invasion by non-indigenous plant species, except in alpine environments where non-indigenous species did not perform well.

Influence of changes in sagebrush on Gunnison sage grouse in southwestern Colorado. S.J. Oyler-McCance, K.P. Burnham, and C.E. Braun. 2001. Southwestern Naturalist 46:323-331. (Dept. of Biological Sci., Univ. of Denver, Denver, CO 80208). Documented a loss of 155,673 hectares of sagebrush steppe in southwestern Colorado between 1958 and 1993.

Nitrogen deposition and forest expansion in the northern Great Plains. M. Kochy and S.D. Wilson. 2001. Journal of Ecology 89:807-817. (S.D. Wilson, Dept. of Biology, Univ. of Regina, Regina, SK S4S 0A2, Canada). Even low rates of atmospheric nitrogen deposition may accelerate the expansion of trees into temperate grasslands.

Nutritional quality of shinnery oak buds and catkins in response to burning or herbivory. C.S. Boyd, L.T. Vermeire, T.G. Bidwell, and R.L. Lochmiller. 2001. Southwestern Naturalist 46:295-301. (Eastern Oregon Agr. Research Center, HC 71 Box 451, Hwy 205, Burns, OR 97720). The nutritive quality of shinnery oak buds and catkins is high, but they also contain high levels of phenolic compounds that reduce their forage value.
Shrubland ecosystem genetics and biodiversity: Proceedings. E.D. McArthur and D.J. Fairbanks (eds.). 2001. USDA Forest Service Rocky Mountain Research Station RMRS-P-21. (Publications Room, Rocky Mountain Research Station, $32425^{\text {th }}$ Street, Ogden, UT 84401). This bulletin contains the 53 papers from the $11^{\text {th }}$ Wildland Shrub Symposium at Provo, Utah in June 2000.

\section{Socioeconomics}

Farm and ranch recreation handbook. S.J. Rottman and J. Powell. 2001. (\$25; Wyoming Agricultural Experiment Station, c/o J. Powell, Dept. of Renewable Resources, Univ. of Wyoming, Laramie, WY 82001). A practical guidebook for ranchers who want to develop a recreational enterprise.

United States grasslands and related resources: An economic and biological trends assessment. $R$. Conner, A. Seidl, L. VanTasse11, and N. Wilkins. 2001. (Dept. of Agricultural Economics, Texas A\&M Univ., College Station, TX 77843). Discusses the decrease in grassland acreage across the U.S. and suggests that government policies should provide incentives to retain or restore grasslands.

Author is professor of range science and extension range management specialist, Dept. of Animal and Range Sciences, Montana State Univ., Bozeman, MT 59717. 


\section{Letters to the Editor}

With over 50 years membership in SRM, I had never felt the need to complain much about the goings-on in the organization. But after reading the December issue of Rangelands, the bad news and the good news carried in that issue got to me!

The bad news is that use of a term "livestock-free rangeland" is one of the most absurd things I have ever heard. And, then to read where a Society name change is being mentioned to delete the word "Range" from our name also makes me think that $\mathrm{I}$ am now living in a different time.

The good news is the letter from Bob Ross, which states "Wake Up America"!!

I think I was born 50 years too soon. And, our "Journey to Change' looks like it might become a "Journey to Oblivion"!!

\section{Chuck Saulisberry}

The December 2001 issue of Rangelands contains several thought-provoking items on the future of the range management profession and of SRM. McClaran et al, Box, and Kothmann each address the decline of membership in SRM and the apparent loss of relevance to society of range management. It seems that livestock and grazing management have been transformed from the cornerstone of most range professionals' expertise to a kind of millstone around our necks. Kothmann suggests that SRM must adapt to the changing values of American society by changing its identity (including its name), its vision and its mission to better conform. I would like to play Devil's advocate and argue that we NOT try to conform and adapt to society's ever-changing values, but rather continue to be what SRM members have traditionally been-the nation's foremost experts in GRAZING!

Despite the encroachment of urbanization on the Western rangelands, despite the bad rep of red meat, despite all the social trends so well described by McClaran et al., there is still a substantial presence of rangeland livestock in this country and abroad. The global population trends documented in the December issue by Holechek will demand intensified use of rangelands for producing food and fiber from grazing animals, at least in developing countries, far into the foreseeable future. There will therefore continue to be a profound need for expertise in the field of sustainable ran geland livestock production. Rather than trying to shoehorn the varied interests of hydrologists, sociologists, landscape architects and recreational planners into SRM we should cleave to the core set of interests and knowledge that the public and indeed most of us identify with range management - the complex ecology and management of grazing. Sure, plenty of us are interested in non-grazing wildlife and areas of science other than grazing ecology, but we are members of this particular professional society because it best represents our interests in grazing.

SRM can persist and grow by reaching out globally to those nations where rangeland livestock is still a vitally important industry. Why not merge with African, Australian, Latin American and Asian rangeland societies to form a truly international professional group, to the benefit of all parties? We should relax about the declining US membership, accepting that we are not a trendy profession but holding firm to our identity as students and aficionados of grazing. If declining membership revenues force each of us to cough up more dues then we should do so cheerfully to ensure the persistence of a professional society that represents our core interests, not the latest American values fad.

Pete Sundt, Rangeland Consultant

12926 The Long Rd, Pima, Arizona 85543

\section{Requiescat in Pace}

Joseph Frank Pechanec, 91 of Boise, Idaho died on Friday December 14, 2001 with his daughters and grandchildren pre-

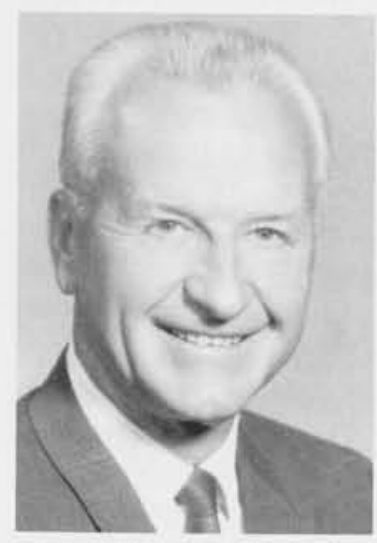
sent.

Joe was preceded in death by his wife Genevieve, son Ted, one brother and two sisters.

He was born north of Nampa, Idaho on March 9, 1910. A son of Joseph and Anna Chleboun Pechanec. He and Genevieve E Garvin were married in Rexburg, Idaho on May 29, 1941.

Joe graduated from high school in Nampa, Idaho in 1927, and with a B.S. degree in range management and forestry from the University of Idaho, Moscow, Idaho in 1932.

For 40 years he was employed as range ecologist (research) and forester by the U.S. Forest Service with headquarters in Idaho, Utah, Oregon, Washington, D.C. and Asheville, North Carolina.

During his career he served on foreign assignments in Somalia, Africa, the Middle East and Iran. He served in several scientific and professional societies concerned with forest, rangelands, and watersheds. He was active in formation of the National Society for Range Management and served as its first president in 1948 and editor in 1953.

He authored more than 60 scientific publications. For his contributions and scientific leadership he received several awards including honorary Doctor of Science from the University of Idaho, the Superior Service award from the USDA, Outstanding Achievement award from the Society for Range Management, and Distinguished Alumnus Award from University of Idaho 1989.

He is survived by two daughters, Mrs. Patricia (A.V. Pusateri of Dallas, Texas, Mrs. Joan (Charles) Price of Redding, California, and six grandchildren.

Genevieve G. Pechanec, died December 2, 2001. She was born in Boise, Idaho on May 5, 1907. Most of her teen and young adulthood years were spent in Pocatello, Idaho. Her parents were Martin M. Garvin and Ellen O'Reilly Garvin. She was the sixth of eight children.

Genevieve served as Director of Volunteers at St. Benedict's Hospital for three years. She was active in St. Joseph Catholic Church, served on the Community Council of Social Services, was on the Y.M.C.A. board. 


\section{Book Review}

Fluid Arguments. Edited by Char Miller. 2001. The University of Arizona Press, Tucson. 354 pp. US $\$ 45.00$ cloth. ISBN 0-8165-2061-5.

Fluid Arguments is an edited collection of sixteen chapters whose purpose is to frame contemporary water debates in the western United States (the 'West') in their historical context. As the jacket cover of the book explains:

"Fluid Arguments clearly shows that many of the current disputes over water take place without a real appreciation for the long history of the debate. By shedding new light on how water allocation is established-and who controls it - this book makes a vital contribution to our understanding of water and growth in the region."

The seventeen contributors have expertise in history, geography, ethnography, political science, law, and urban studies. The book begins with an introduction by the editor summarizing the chapters and tying them into a cohesive whole. Chapters cover Spanish colonial water laws, Native American water rights, the historic competition for agricultural irrigation water, and the era of dam building. The final chapter offers a prospective on future water-related challenges facing the west.

The collection is well written and logically organized. Readers in fields other than history, geography and political science will find the book easy to read. The introduction provides a well-crafted summary of each chapter and how the chapters are related. The chapters are concise and fascinating to read. The initial chapters on the water usage and rights of indigenous populations prior to the westward expansion of the United States provide an excellent foundation for understanding the modern-day conflict between Native American water rights and the prior appropriative water rights sanctioned by western states. An ensuing chapter on "Winters" water rights nicely sets out the history of how Native American water rights-overlooked by state and federal governments as water was being fully appropriated into state water systems - came to be legally recognized and enforced by the federal government. Readers gain an understanding of why the federal government has intervened in state water right systems to ensure that "Winters" rights receive their due legal recognition. Later chapters investigate the era of federal dam building in the West and the economic benefits that it provided to the region. Readers gain an understanding of the economic and environmental costs that have brought the era to a close in the modern age. The writers approach these controversial subjects evenhandedly. The final chapter justifies nicely the need for the West to achieve a wider allocation of water among traditional appropriative and emerging non-appropriative uses.

A significant criticism of this collection is that its scope is overly limited to achieve the heroic purpose of framing current water debate in its historical context. In particular, the book effectively ignores the role of the prior appropriation doctrine, which is mentioned only peripherally on three pages. This is a peculiar omission given that the doctrine has provided the foundation of western water law for over one hundred and fifty years. Most importantly, the feasibility of modern conflict resolution mechanisms-especially water right exchanges - will be tested against the strictures of this doctrine. Without developing the institutional foundation provided by the prior appropriation doctrine, the collection can give only shallow coverage of the potential impact of water marketing on the western economy. For example, the final chapter makes a case that water-rights exchanges should be used to reallocate water from irrigated agriculture to more valued urban uses, but lacks the institutional background to investigate why such exchanges have been unable to develop significantly within the framework of the prior appropriation doctrine.

In sum, the book is a useful resource within a limited context. It provides an excellent background for understanding the important topics of Native American water usage and rights, and the era of dam building in the West. The book is recommended for use by water professionals, scholars, and students in graduate and undergraduate classes. Surprisingly, the collection ignores the cornerstone of western water lawthe prior appropriation system. The historical context provided by this doctrine must be provided by another text. This omission severely limits what the collection can say about current water policy issues.--Ray Huffaker, Washington State University, Pullman, Washington. 
